\title{
Dexamethasone priming enhances stemness and immunomodulatory property of tissue-specific human mesenchymal stem cells
}

\author{
Sonali Rawat ${ }^{1}$ (1), Vatsla Dadhwal ${ }^{2}$ and Sujata Mohanty ${ }^{\text {* }^{*}}$
}

\begin{abstract}
Background: Human Mesenchymal Stem Cells (hMSCs) represent a promising cell source for cell-based therapy in autoimmune diseases and other degenerative disorders due to their immunosuppressive, anti-inflammatory and regenerative potentials. Belonging to a glucocorticoid family, Dexamethasone (Dex) is a powerful anti-inflammatory compound that is widely used as therapy in autoimmune disease conditions or allogeneic transplantation. However, minimal immunomodulatory effect of hMSCs may limit their therapeutic uses. Moreover, the effect of glucocorticoids on the immunomodulatory molecules or other regenerative properties of tissue-specific hMSCs remains unknown.
\end{abstract}

Method: Herein, we evaluated the in vitro effect of Dex at various dose concentrations and time intervals, $1000 \mathrm{ng} /$ $\mathrm{ml}, 2000 \mathrm{ng} / \mathrm{ml}, 3000 \mathrm{ng} / \mathrm{ml}$ and $24 \mathrm{~h}, 48 \mathrm{~h}$ respectively, on the basic characteristics and immunomodulatory properties of Bone marrow derived MSC (BM-MSCs), Adipose tissue derived MSCs (AD-MSCs), Dental Pulp derived MSC (DPMSCs) and Umbilical cord derived MSCs (UC-MSCs).

Results: The present study indicated that the concentration of Dex did not ramify the cellular morphology nor showed cytotoxicity as well as conserved the basic characteristics of tissue specific hMSCs including cell proliferation and surface marker profiling. However, quite interestingly it was observed that the stemness markers (Oct-4, Sox-2, Nanog and KIf-4) showed a significant upregulation in DP-MSCs and AD-MSCs followed by UC-MSCs and BM-MSCs. Additionally, immunomodulatory molecules, Prostaglandin E-2 (PGE-2), Indoleamine- 2,3-dioxygenase (IDO) and Human Leukocyte Antigen-G (HLA-G) were seen to be upregulated in a dose-dependent manner. Moreover, there was a differential response of tissue specific hMSCs after pre-conditioning with Dex during mixed lymphocyte reaction, wherein UC-MSCs and DP-MSCs showed enhanced immunosuppression as compared to AD-MSCs and BMMSCs, thereby proving to be a better candidate for therapeutic applications in immune-related diseases.

Conclusion: Dex preconditioning improved the hMSCs immunomodulatory property and may have reduced the challenge associated with minimal potency and strengthen their therapeutic efficacy.

Keywords: Mesenchymal stem cell, Immunomodulatory, Glucocorticoids, Dexamethasone, Autoimmune diseases, Anti-inflammatory, Allogenic

\footnotetext{
*Correspondence: drmohantysujata@gmail.com

1 Stem Cell Facility, All India Institute of Medical Science, New Delhi, India

Full list of author information is available at the end of the article
} original author(s) and the source, provide a link to the Creative Commons licence, and indicate if changes were made. The images or other third party material in this article are included in the article's Creative Commons licence, unless indicated otherwise in a credit line to the material. If material is not included in the article's Creative Commons licence and your intended use is not permitted by statutory regulation or exceeds the permitted use, you will need to obtain permission directly from the copyright holder. To view a copy of this licence, visit http://creativecommons.org/licenses/by/4.0/. The Creative Commons Public Domain Dedication waiver (http://creativeco mmons.org/publicdomain/zero/1.0/) applies to the data made available in this article, unless otherwise stated in a credit line to the data. 


\section{Graphical Abstract \\ Preconditioning of tissue specific hMSCs with dexamethasone biomanufacturers the enhanced potential}

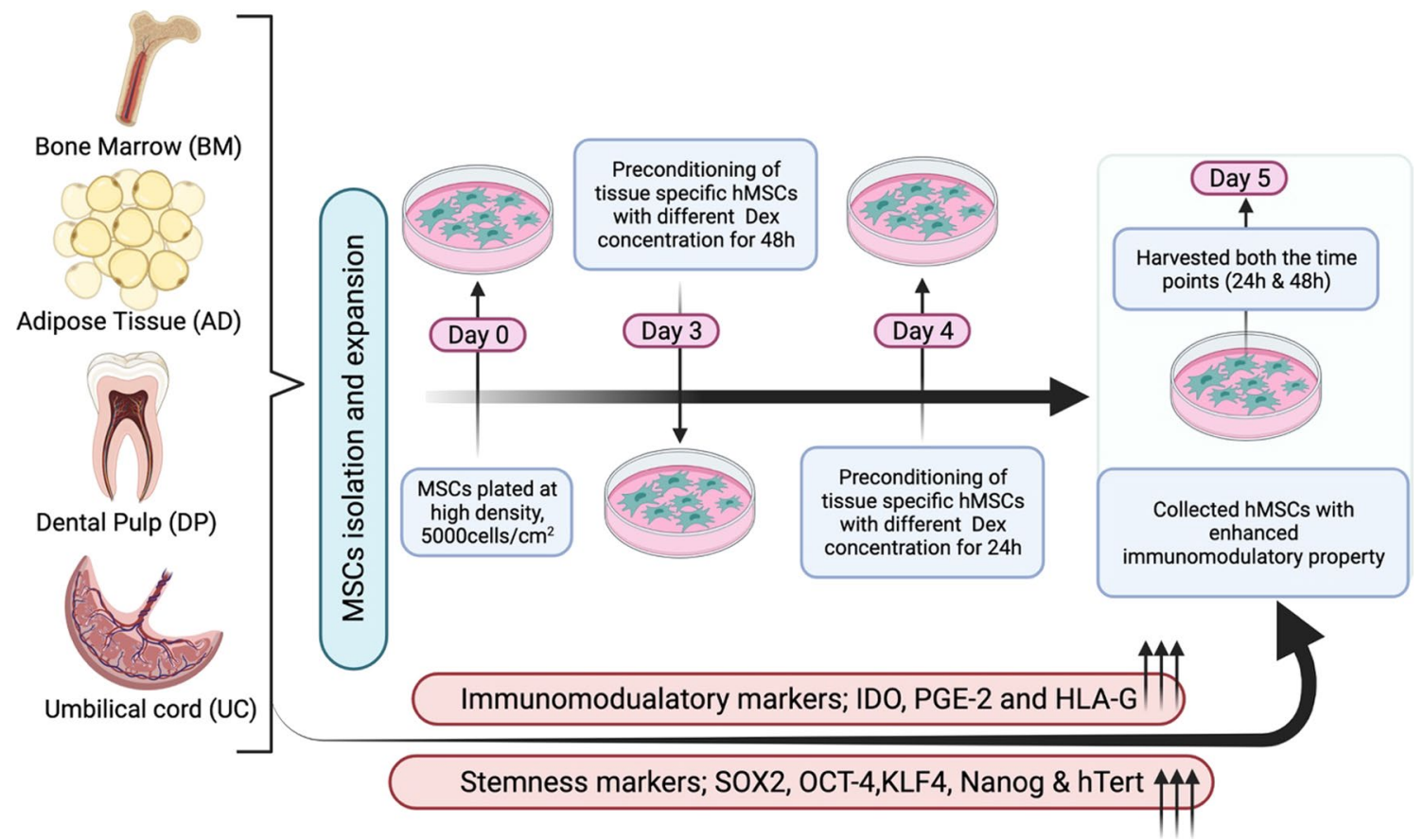

hMSCs with better stemness and immunomodulatory properties for future therapeutics.

\section{Background}

Despite the many advancements in the area of immunosuppressive therapy, graft rejection and graft versus host disease (GvHD) remain the leading cause of post-transplantation mortality [1]. To disparage the risk associated with alloreactivity, immunosuppressive drugs (ISD) like cyclosporine A (CsA), tacrolimus, and mycophenolic acid (MPA) are regular regime after allogeneic transplantation, out of which MPA blocks the calcineurin pathway and results in inhibiting $\mathrm{T}$ cell responses. On the other hand, the functional component of mycophenolate mofetil is an anti-proliferative drug that suppresses guanine generation by blocking inosine monophosphate dehydrogenase (IMPDH), respectively $[2,3]$. Dexamethasone (Dex) is a strong synthetic member of the glucocorticoid class of steroid drugs that act as an antiinflammatory and immunosuppressant molecule [4]. To achieve systemic inhibition of inflammatory and immune response, the steroids influence various levels of antigen presentation, immune cell proliferation, and cytokine production [5]. Therefore, dexamethasone impacts cellular DNA, thereby changing gene transcription [6]. Whereas, use of Dex to treat autoimmune diseases and to prevent the rejection of transplanted organs or tissues in the host, their impact is often followed by detrimental side effects such as nephrotoxicity or osteoporosis, which may diminish their overall benefits $[3,4]$.

The scientific and clinical interest in human mesenchymal stem cells (hMSCs) has rampant in the past decade, highlighting their role in tissue repair and immunomodulatory properties [7-10]. hMSCs are a plastic adherent heterogeneous population of cells having a fibroblast-like morphology, form colonies in vitro, and can differentiate into adipocytes, chondrocytes, and osteocytes [7]. They can be isolated from different organs and tissues, including bone marrow, adipose tissue, dental pulp, muscles, and feto-maternal organs [7]. These cells are known for having low immunogenicity, being able to escape immune cognizance due to negative expression of HLAclass II, and have abilities to express co-stimulatory molecules. hMSCs are also capable of secreting a wide panel of trophic factors and immunomodulatory factors that suppress the local immune response and initiate tissue repair [11, 12]. hMSCs immunoregulatory mechanism is a multifactorial process involving both cells to cell contact and cell-free paracrine signaling. hMSCs secrete a panel of various immunomodulatory factors which aid in reparative and immunosuppressive role [7, 9]. This 
includes, non-classical HLA-G is one of the influential immunosuppressive molecules, which plays an important role in fetal-maternal tolerance during pregnancy, protecting the fetus from maternal immune cell invasion, and an organ/cell transplantation [13, 14]. Due to the presence of a unique gene promoter at the transcriptional level, the expression of HLA-G is mainly controlled as compared to the classical HLA-class I gene. However, at the post-transcriptional level and after alternate splicing, the primary transcript splits into seven isoforms, out of which four membrane-bound proteins (HLA-G1 to G4) and three are soluble proteins (HLA-G5 to G7). Due to different isoforms, it acts via cell-cell contact or contacts independent action [15].

On the other hand, the molecule generated by Cyclooxygenase (COX-1 and COX-2) enzymes, PGE-2, constitutes another major molecule secreted by hMSCs that exert well-defined actions in a broad spectrum of physiological and pathological settings [16]. It was reported that inflammation conditions led to the upregulation of PGE-2 secretion with it, not only participating in inflammatory response but also initiating proliferation and migration of various cell types [16]. However, there are various possible procedures to prevail hMSCs with enhanced immunosuppressive properties and the potential roles of specific immunomodulatory molecules, which are differentially upregulated in certain culture conditions. Also, various studies have shown that the expression of several molecules implied in hMSCs immunomodulation is regulated by exposure to proinflammatory molecules such as IFN- $\gamma$, TNF- $\alpha$, IL-1, and IL-6, etc. [17-19]. Nevertheless, such exposure could also increase hMSCs immunogenicity, impair hMSCs differentiation capacity, and diminish cellular viability [20]. Taking all the above-said attributes into consideration of immunosuppressive drugs, the pre-conditioning treatment approach using immunosuppressive agents with hMSCs may offer a promising alternative strategy, reducing the dosage of immunosuppressive drugs conventionally administered and also improving their efficacy. Therefore, possible caveats must be considered for the use of primed hMSCs, especially for their allogeneic implantation. Therefore, preconditioning hMSCs with steroid, pro-inflammatory cytokine in vitro, before their in vivo administration, is an interesting approach for improving their therapeutic potential.

Reports about the Dex effect on hMSCs gene profile had already been studied and it is widely accepted that Dex is one of the major components for differentiation of hMSCs to osteogenic, Chondrogenic, and Adipogenic [21]. However, available data showed that Dex inhibits the osteogenic differentiation of hMSCs and creates a shift to Adipogenic differentiation in a dose-dependent manner, i.e., at $10^{-7} \mathrm{~mol} / \mathrm{L}$. Interestingly, low-dose Dex $\left(10^{-8} \mathrm{~mol} / \mathrm{L}\right)$ maintains the cell-surface marker profile of hMSCs over multiple passages [22]. However, much focus has been paid to the effect of Dex on hMSCs proliferation and differentiation. Reports are comparing the differential abilities of tissue specific hMSCs, specifically, placenta-derived hMSCs shown to possess a better proliferative rate and superior engraftment capacity, to share some of the same markers as embryonic stem cells (ESCs) and to present increased immunosuppressive properties $[9,10]$.

However, the potent immunosuppressive capacity is being considered as a very important feature of hMSCs. In the present study, we have evaluated the effect of Dex in the dose and time-dependent manner on tissue specific hMSCs regenerative properties, immunomodulatory factors, and their in vitro ability to inhibit the proliferation of immune cells.

\section{Methods \\ Isolation and expansion of tissue-specific hMSCs \\ from bone marrow, adipose tissue, dental pulp, and umbilical cord tissue}

The study was approved by the Institutional Committee for Stem Cell Research (ICSCR), All India Institute of Medical Sciences (AIIMS), New Delhi, India (Ref No. ICSCR/54/16(R)). All the samples were obtained after taking the donor's informed consent.

Bone marrow was collected from the donor undergoing the routine medical test procedure in the Department of Hematology, AIIMS, New Delhi. Briefly, BM-MSCs were isolated and cultured as previously described [23, 24]. For Adipose tissue, the sample was collected from the patients undergoing a pre-scheduled surgical procedure in the Department of Pediatric Surgery, AIIMS, New Delhi. The sample was collected in a $5 \mathrm{ml}$ transport vial containing Dulbecco's Modified Eagle Medium (DMEM)-Low Glucose (LG) without FBS with 1\% Penicillin $(100 \mathrm{U} / \mathrm{ml})$, Streptomycin $(100 \mu \mathrm{g} / \mathrm{ml})+$ Gentamycin $(250 \mu \mathrm{g} / \mathrm{ml})$. The Sample was washed extensively with $1 \mathrm{X}$ PBS containing $1 \%$ Penicillin $(100 \mathrm{U} / \mathrm{ml})+$ Streptomycin $(100 \mu \mathrm{g} / \mathrm{ml})+$ Gentamycin $(250 \mu \mathrm{g} / \mathrm{ml})$ (Gibco, USA). Then explants $(\sim 2 \mathrm{~mm})$ were carefully placed in a $35 \mathrm{~mm}$ culture dish and kept undisturbed, incubated overnight at $37{ }^{\circ} \mathrm{C}$ and $5 \% \mathrm{CO}_{2}$. The next day, as the tissue got adhered to the surface, complete media was added and the medium changed every 3-4 days. When cells started growing and migrating out of the explant and reached $80 \%$ confluence, cells were harvested using $0.05 \%$ trypsin-EDTA (Invitrogen-Gibco, USA) and transferred into a $60 \mathrm{~mm}$ culture dish. Dental pulp derived hMSCs were obtained from the third molar of each individual (16-18 years) who came for orthodontic treatment at the 
Department of Orthodontics and Dento-Facial Deformities, Centre for Dental Education and Research (CDER), AIIMS, New Delhi. Briefly, DP-MSCs were isolated and cultured as previously described protocol [24, 25].

Umbilical Cord derived MSCs were collected and processed within $24 \mathrm{~h}$ of normal or cesarean delivery from the Department of Obstetrics and Gynecology, AIIMS, New Delhi. Briefly, Umbilical Cord was collected in a $50 \mathrm{ml}$ Schott bottle containing 1XPBS with 1\% Antibiotics (Penicillin, Streptomycin, and Gentamycin). Upon the arrival of the sample, it was washed extensively with 1XPBS containing $1 \%$ Antibiotics. The artery part of the cord was exposed using the sharp surgical blade and it was chopped into a small piece (approx. $\sim 2 \mathrm{~mm}$ ) the exposed jelly part of the cord was placed in a $35 \mathrm{~mm}$ culture dish and kept undisturbed. The cultures were incubated overnight at $37{ }^{\circ} \mathrm{C}$ and $5 \% \mathrm{CO}_{2}$ with $1 \mathrm{ml}$ complete medium and changed every three to four days. When cells started growing and migrating out of the explant and reached $80 \%$ confluence, cells were harvested using $0.05 \%$ trypsin-EDTA (Invitrogen-Gibco, USA) and transferred into a $60 \mathrm{~mm}$ culture dish.

Cultures were monitored by phase-contrast microscopy (Olympus, Central Vally, PA) to evaluate the cell morphology and confluency. All assays were performed using tissue-specific hMSCs at passage 3, after their immunophenotypic characterization.

\section{Pre-conditioning of tissue-specific hMSCs with dex}

Stock concentration of Dex (Cat.No. D1756, Sigma, USA) was prepared as per the manufactures protocol. Further, the working concentration was directly prepared in the cell culture medium. Harvested cells were incubated in serum-free medium (control) or in serum-free medium containing various doses of Dex $(1000 \mathrm{ng} / \mathrm{ml}, 2000 \mathrm{ng} /$ $\mathrm{ml}, 3000 \mathrm{ng} / \mathrm{ml}$ ) for assessing the effect of these drugs on immunomodulatory molecules (PGE-2, IDO and HLAG) and stemness markers (Sox-2, Oct-4, Klf-4, Nanog, hTERT) expressed by tissue specific hMSCs. The cells were collected after different exposure times ( $24 \mathrm{~h}$ and $48 \mathrm{~h}$ ) at all three drug concentrations of Dex. Real-time PCR, Immunofluorescence (IF) staining, Flow cytometry, and ELISA were conducted on the groups, which were collected after $24 \mathrm{~h}$, and $48 \mathrm{~h}$ of drug exposure. All the experiment was performed at passage 3 .

\section{Live/dead assay of hMSCs treated with Dex}

20,000 cells per well of 24 well plate was plated with tissue specific hMSCs in serum-free culture medium as described previously for $24 \mathrm{~h}$ and $48 \mathrm{~h}$ with different concentrations of Dex $(1000 \mathrm{ng} / \mathrm{ml}, 2000 \mathrm{ng} / \mathrm{ml}$, $3000 \mathrm{ng} / \mathrm{ml}$ ). The Live/Dead assay was performed with
Calcein- ethidium homodimer dye (Invitrogen, USA). The sample size for each group's live/dead assay was kept three $(\mathrm{n}=3)$.

\section{Measurement of metabolic activity by MTT assay of hMSCs treated with dex}

The proliferation rate of hMSCs $(\mathrm{n}=3)$ treated without Dex treatment and with Dex treatment was performed. Briefly, 5000 cells per well were seeded in triplicates, and at each termination day (1, 3, 5 and 7) medium was removed and replenish with fresh $180 \mu \mathrm{l}$ of complete medium and $20 \mu \mathrm{l}$ of 3-(4, 5-Dimethylthiazol-2-yl)2,5-diphenyltetrazolium bromide (MTT) (Sigma, USA) reagent was added. The plate was incubated for $3-4 \mathrm{~h}$ at $37{ }^{\circ} \mathrm{C}$ and $5 \% \mathrm{CO}_{2}$. Followed by removal of medium and formazan crystals were dissolved with $200 \mu \mathrm{l}$ of DMSO. The solution was collected in a fresh plate and absorbance were taken at 570 and $660 \mathrm{~nm}$ using ELISA reader (BioTek, Germany). The technique was performed as per the previously established protocol [24].

\section{Scratch assay}

To examine whether different concentration and time points of Dex affects the migratory property of tissue specific hMSCs. Tissue specific hMSCs were plated at 50-60\% confluency before preconditioning. Culture plates were incubated at $37{ }^{\circ} \mathrm{C}$ and $5 \% \mathrm{CO}_{2}$ until confluency reaches $80-90 \%$. Cells were pre-treated with $1000 \mathrm{ng} / \mathrm{ml}, 2000 \mathrm{ng} / \mathrm{ml}$ and $3000 \mathrm{ng} / \mathrm{ml}$ of Dex for $24 \mathrm{~h}$ and $48 \mathrm{~h}$ in serum-free medium. Followed by PBS wash, a scratch was created using p200 pipet on cells monolayer. Again, culture plates were washed with PBS once and replaced with the DMEM-LG with $10 \%$ FBS and $1 \%$ Penicillin $(100 \mathrm{U} / \mathrm{ml})+$ Streptomycin $(100 \mu \mathrm{g} / \mathrm{ml})$. At $0 \mathrm{~h}, 12 \mathrm{~h}, 24 \mathrm{~h}$, the scratch area was imaged using phasecontrast microscopy (Olympus, Central Vally, PA) with a $4 \mathrm{X}$ magnification lens. The analysis of open area was performed using Image J software. The experiment was performed thrice for all the tissue-specific hMSCs.

\section{Trilineage differentiation}

Tissue specific hMSCs were characterized by differentiating cells into osteogenic, chondrogenic and Adipogenic lineages according to the induction protocols described in our earlier published research article [23, 24].

\section{Immunophenotyping}

At passage 3, hMSCs were characterized using monoclonal antibodies specific for CD105-APC, CD73-PE, CD29-FITC, CD90-PerCp-Cy5.5, HLA-ABC-APC, HLADR-FITC, CD34/45-PE/FITC (BD Pharmingen, France). 50,000 cells were incubated with the respective primary 
$\mathrm{mAb}$ or isotype-matched control antibody for $40 \mathrm{~min}$ in dark. Cells were washed with $1 \mathrm{X}$ PBS and analyzed by flow cytometry (BD-LSR-II, San Jose, CA). For HLA-G Flow cytometry studies, the mouse anti-HLA-G1/HLAG5 MEMG/9 PE antibody (Exbio, Praha, Czech Republic) was used at 1:200 final concentration for 75,000 cells and incubated for $40 \mathrm{~min}$ in the dark. For analysis, isotype controls were included. The average of HLA-G was calculated value from 5 donors for all the tissue-specific hMSCs. Acquisition and data analysis were performed using flow cytometry (BD Bioscience) and FACS Diva Software Version 6.2.

\section{Quantitative real-time reverse transcriptase-polymerase chain reaction (qRT-PCR)}

For the isolation of total RNA from cultured tissuespecific hMSCs, the respective T-25 flasks were washed using PBS for the removal of any existing debris or serum. The cells were then trypsinized using TrypsinEDTA, mixed with complete media, and pellet down at $300 \mathrm{~g}$ (Beckman Coulter, California, USA) for $5 \mathrm{~min}$. The cells were transferred into microcentrifuge tubes (MCT) and were then lysed using TRI reagent (Molecular Research Centre, Ohio, USA), $1 \mathrm{ml} / 1 \times 10^{6}$ cells. The total RNA was prepared according to the phenol-chloroform extraction method. The concentration and optical density (OD) of samples were recorded using a Nanophotometer (Implen, Germany). Reverse Transcriptase PCR: cDNA was prepared, using $2 \mu \mathrm{g} / \mu \mathrm{l}$ of the RNA samples from tissue-specific hMSCs and JEG-3, HeLa cell lines by Reverse transcriptase (RT) enzyme (Promega, USA). Optimization of cDNA using GAPDH: Glyceraldehyde -3 phosphate dehydrogenase (GAPDH) was used in the PCR setup as the housekeeping gene, for the optimization of the prepared cDNA samples of tissue-specific hMSCs, JEG-3 and, HeLa. qPCR was performed in duplicates using SYBR green Master Mix according to the manufacturer's instruction (Kappa, USA). We calculated the average fold change for PGE-2, IDO and HLA-G value from 5 donors. However, for stemness markers studies, the average value of 3 donors were considered for tissue-specific hMSCs in duplicate using an equation of the standard curve. List of primers (Table 1).

\section{ELISA for PGE-2 and HLA-G}

Tissue specific hMSCs, pre-treated with different concentrations of Dex $(1000 \mathrm{ng} / \mathrm{ml}, 2000 \mathrm{ng} / \mathrm{ml}, 3000 \mathrm{ng} /$ $\mathrm{ml}$ ) for $24 \mathrm{~h}$ and $48 \mathrm{~h}$, were seeded in 6 well plates at 50,000 cells/well and cultured for respective time and dose concentration in $2 \mathrm{ml}$ medium without FBS. Culture supernatant was then collected and the concentration of
Table 1 List of primers

\begin{tabular}{|c|c|c|c|c|c|}
\hline \multirow{2}{*}{$\frac{\text { S. Nos }}{1}$} & \multirow{2}{*}{$\begin{array}{l}\text { Gene } \\
\text { OCT-4 }\end{array}$} & \multicolumn{2}{|c|}{ Sequence } & \multirow{3}{*}{$\begin{array}{l}\mathrm{Tm} \\
59.6\end{array}$} & \multirow{3}{*}{$\begin{array}{l}\text { Company } \\
\text { Sigma }\end{array}$} \\
\hline & & FP & $\begin{array}{l}5^{\prime}-A G C G A A C C A G T A T C G A G A \\
\text { AC-3' }\end{array}$ & & \\
\hline & & $\mathrm{RP}$ & $\begin{array}{l}\text { 5'-TTACAGAACCACACTCGG } \\
\text { AC-3' }\end{array}$ & & \\
\hline \multirow[t]{2}{*}{2} & Sox-2 & FP & $\begin{array}{l}\text { 5'-AGCTACAGCATGATGCAG } \\
\text { GA-3' }\end{array}$ & 59.6 & Sigma \\
\hline & & $\mathrm{RP}$ & $\begin{array}{l}\text { 5'-GGTCATGGAGTTGTACTG } \\
\text { CA-3' }\end{array}$ & & \\
\hline \multirow[t]{2}{*}{3} & Nanog & FP & $\begin{array}{l}\text { 5'-TGAACCTCAGCTACAAAC } \\
\text { AG-3' }\end{array}$ & 59.6 & Sigma \\
\hline & & $\mathrm{RP}$ & $\begin{array}{l}\text { 5'-TGGTGGTAGGAAGAGTAA } \\
\text { AG-3' }\end{array}$ & & \\
\hline \multirow[t]{2}{*}{4} & Klf-4 & $\mathrm{FP}$ & $\begin{array}{l}\text { 5'-TCTCAAGGCACACCTGCG } \\
\text { AA-3' }\end{array}$ & 59.6 & Sigma \\
\hline & & $\mathrm{RP}$ & 5'-TAGTGCCTGGTCAGTTCATC-3' & & \\
\hline \multirow[t]{2}{*}{5} & hTERT & $\mathrm{FP}$ & $\begin{array}{l}\text { 5'-ACCAAGCATTCCTGCTCA } \\
\text { AGCTG-3' }\end{array}$ & 55.7 & Eurofin \\
\hline & & $\mathrm{RP}$ & $\begin{array}{l}\text { 5'-CGGCAGGTGTGCTGGACA } \\
\text { CTC-3' }\end{array}$ & & \\
\hline \multirow[t]{2}{*}{6} & HLA-G & FP & $\begin{array}{l}\text { 5'-CTGACCGAGACCTGGGCG } \\
\text { GGCT-3' }\end{array}$ & 60.8 & Sigma \\
\hline & & $\mathrm{RP}$ & $\begin{array}{l}\text { 5'-GGCTCCATCCTCGGACAC } \\
\text { GCCGA-3' }\end{array}$ & & \\
\hline \multirow[t]{2}{*}{7} & IDO & $\mathrm{FP}$ & $\begin{array}{l}\text { 5'-CCTGAGGAGCTACCATCT } \\
\text { GC-3' }\end{array}$ & 50.7 & Sigma \\
\hline & & $\mathrm{RP}$ & 5'-TCAGTGCCTCCAGTTCCTTT-3' & & \\
\hline \multirow[t]{2}{*}{8} & PGE-2 & $\mathrm{FP}$ & $\begin{array}{l}\text { 5'-ACTCTGGCTAGACAGCGT } \\
\text { AA-3' }\end{array}$ & 62.8 & Sigma \\
\hline & & $\mathrm{RP}$ & 5'-ACCGTAGATGCTCAGGGAC-3' & & \\
\hline \multirow[t]{2}{*}{9} & GAPDH & $\mathrm{FP}$ & $\begin{array}{l}\text { 5'-GAC AAG CTT CCC GTT CTC } \\
\text { AG-3' }\end{array}$ & 55 & Sigma \\
\hline & & $\mathrm{RP}$ & $\begin{array}{l}\text { 5'-GAC AAG CTT CCC GTT CTC } \\
\text { AG-3' }\end{array}$ & & \\
\hline
\end{tabular}

PGE-2 determined by ELISA (Cayman, USA), whereas HLA-G has been determined by ELISA kit (Biovender, USA). Each group of different Dex concentrations was performed in duplicates $(n=3)$ for all tissue specific hMSCs.

\section{IDO activity}

The biological activity of IDO was calculated by measuring the level of kynurenine in supernatant collected from different preconditioned tissue-specific hMSCs. Briefly, $100 \mu \mathrm{l}$ of collected cell culture supernatant were added to the Eppendorf tube and $50 \mu \mathrm{l}$ of $30 \%$ trichloroacetic acid (Sigma, USA) were added, the tube was vortexed and centrifuged at $8000 \mathrm{~g}$ for $5 \mathrm{~min}$. Then, $75 \mu \mathrm{l}$ of the supernatant was transferred with an equal volume of Ehrlich reagent (100 $\mathrm{mg} \mathrm{p}$-dimethyl benzaldehyde in $5 \mathrm{ml}$ glacial acetic acid) (Sigma, USA) to a 96-well microtiter plate 
and recorded the absorbance at $490 \mathrm{~nm}$ [26]. Experiment was performed at least in three independent setups.

\section{Immunosuppression activity of tissues specific on peripheral blood mononuclear cells (PBMCs)}

The study was approved by the Institutional Ethics Committee (IEC) (Ref No. IECPG-345/07.09.2017, (RT6/29.11.2017). All the samples were obtained after taking the donor's informed consent. Human Peripheral blood mononuclear cells (PBMCs) were isolated by FicollPaque (Axis-Shield; Oslo, Norway) density gradient centrifugation from blood donated by healthy volunteers. Phytohemagglutinin A (PHA (Sigma, USA); $35 \mu \mathrm{g} / \mathrm{mL}$ ) was used to stimulate the activation of human peripheral blood mononuclear cells (PBMCs) before co-culture. For co-culture experiments, hMSCs were treated with Mitomycin C (Sigma, USA); $15 \mu \mathrm{g} / \mathrm{ml}$ and co-cultured $\left(1 \times 10^{4}\right.$ cells/well) with PHA activated hPBMCs $\left(5 \times 10^{4}\right.$ cells/ well) in 1:5 ratio in RPMI-1640 medium (Gibco, USA) containing 10\% FBS for 3 days in 96-well plates (Costar, USA). Proliferation of hPBMCs were assessed by MTS assay. The $200 \mu \mathrm{l}$ cell culture supernatant containing hPBMCs were collected in pre-labelled $0.6 \mathrm{ml}$ Eppendorf tube and $20 \mu \mathrm{l}$ of MTS reagent (Promega, USA) was added in each tube, followed by incubation for $3 \mathrm{~h}$ at $37{ }^{\circ} \mathrm{C}$ and $5 \% \mathrm{CO}_{2}$. Afterwards, tubes were centrifuged at $300 \mathrm{~g}$ for $5 \mathrm{~min}$. $200 \mu \mathrm{l}$ of supernatant was collected from each tube and transferred into the fresh 96 well plate. The absorbance was taken at $490 \mathrm{~nm}$ using ELISA reader (Biotek, Germany). Lastly, \% decrease was calculated by calculating difference between positive control (Activated PBMCs) and test group (MLR). Then; divided the decrease by the positive control and multiplied the answer by 100 .

\section{Statistical analysis}

Statistical analysis was performed using Two wayANOVA, post-test Tukey and $t$-test in GraphPad Instant software (GraphPad Software, Inc.).

\section{Results}

Tissue specific hMSCs were isolated, expanded and characterized according to ISCT guidelines [27]. It was observed that all hMSCs showed plastic adherence and spindle shaped morphology. Surface marker profiling shows $>95 \%$ positivity for CD105, CD90, CD73, CD29, HLA-Class I and negative for HLA-class II, CD34/45. Further, all the tissue specific hMSCs were induced to trilineage differentiation i.e., Osteocytes, Adipocytes and Chondrocytes. Where osteocytes differentiation was confirmed using alizarin red staining representing mineralization of cells, where oil red 'o' staining reveals oil droplets formation and confirms the adipocytes differentiation and chondrocytes differentiation was confirmed using Alcian blue staining (Additional file 1: Fig. S1).

\section{Effect of dexamethasone on basic characteristic properties of tissue specific hMSCs}

Upon preconditioning of hMSCs with different concentrations of Dex at different time points, tissue specific hMSCs did not show any dose and time-dependent response pattern. The range of studied dose concentrations were taken from the available literature [28, 29]. The morphology of BM-MSCs, AD-MSCs, DP-MSCs, and UC-MSCs is presented. They maintained their spindle shape, elongated morphology even at different concentrations and time points of Dex treatment (Additional file 1: Fig. S2).

The live/dead staining was performed to show Dex cytotoxicity (Fig. 1). The green signal shows all live cells whereas the red signal represents the dead cells. However, $1000 \mathrm{ng} / \mathrm{ml}, 2000 \mathrm{ng} / \mathrm{ml}$, and $3000 \mathrm{ng} / \mathrm{ml}$ concentration at different time points of $24 \mathrm{~h}$ and $48 \mathrm{~h}$ did not show any cytotoxic effect on all the tissue specific hMSCs.

MTT assay was performed to evaluate the metabolic activity of the cells after preconditioning with Dex at different concentrations and time points. hMSCs were analyzed for Day 1, Day 3, Day 5 and Day 7 (Fig. 2a, b). The treated and untreated cells showed a typical sigmoid curve for cell metabolic activity, whereas at Day 1 and Day 3 all cells showed the highest proliferation followed by a decreasing trend on Day 7, due to high cell confluency and contact inhibition. Among all the studied groups, no significant difference was observed in Dex treated hMSCs compared to untreated hMSCs.

Furthermore, immunophenotyping was performed for tissue-specific hMSCs upon treatment with different concentrations at various time points. CD105, CD90, CD73, CD29, and HLA-Class I showed $>95 \%$ expression for all the treated and untreated tissue-specific hMSCs, whereas HLA-Class II and CD34/45 showed negative expression for treated as well as untreated tissue-specific hMSCs (Fig. 2c, d).

Various alluring features of hMSCs makes them an ideal candidate to be used for the treatment of several diseases, yet the therapeutic efficacy of hMSCs is unpredictable due to change in inflammation microenvironment and effecting the homing. However, a scratch assay was performed to determine the effect of Dex on the migratory property of hMSCs. The open area was evaluated at $0 \mathrm{~h}, 12 \mathrm{~h}$, and $24 \mathrm{~h}$ in tissue-specific hMSCs (Additional file 1: Fig. S3).

Dex preconditioning shows the upregulated migratory property of hMSCs, specifically BM-MSCs, and DP-MSCs showed the maximum area closure at 


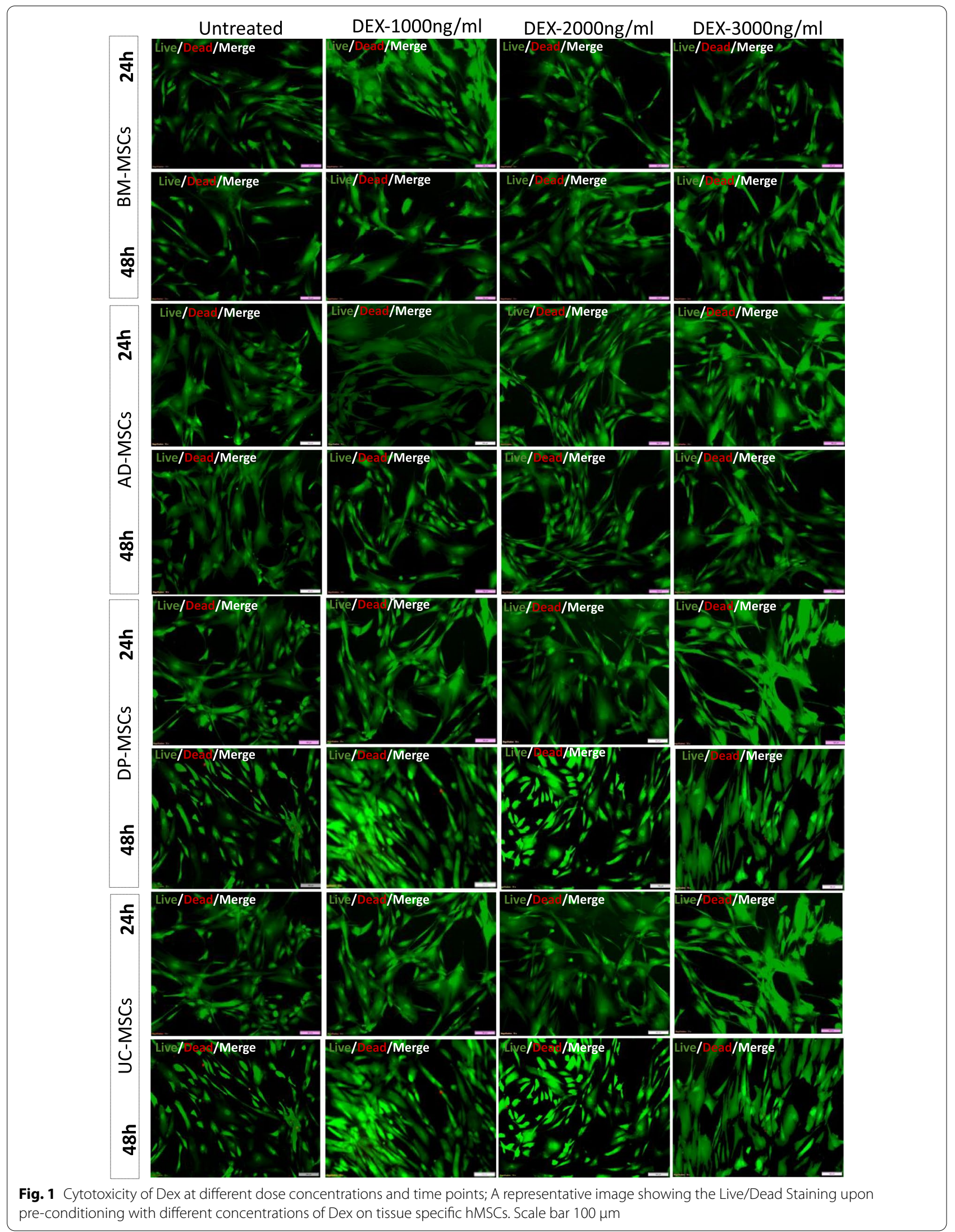




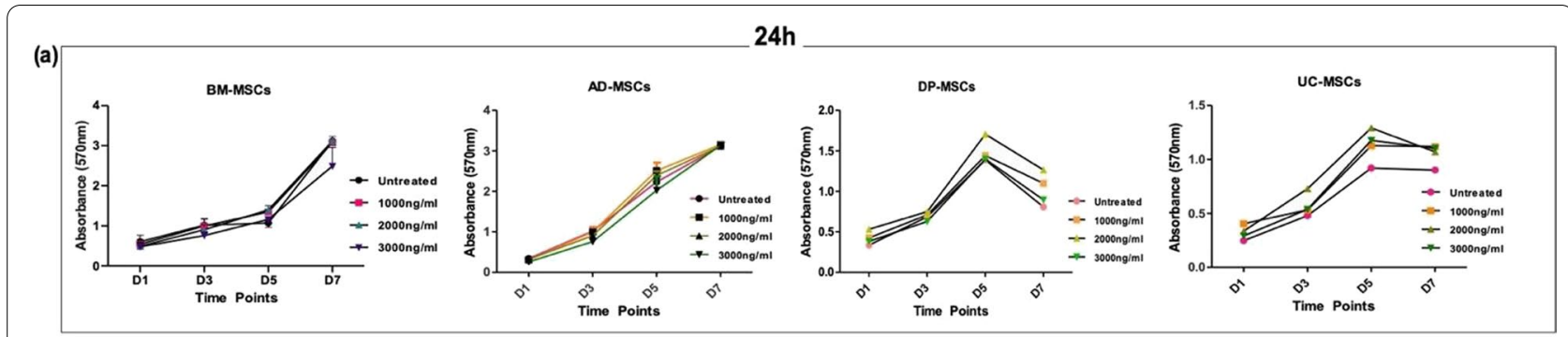

(b)

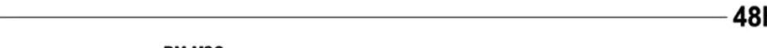

48h
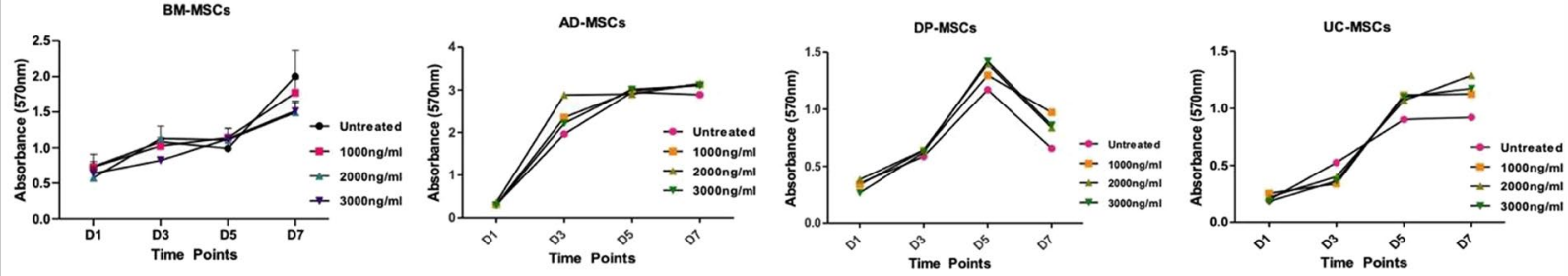

(c)
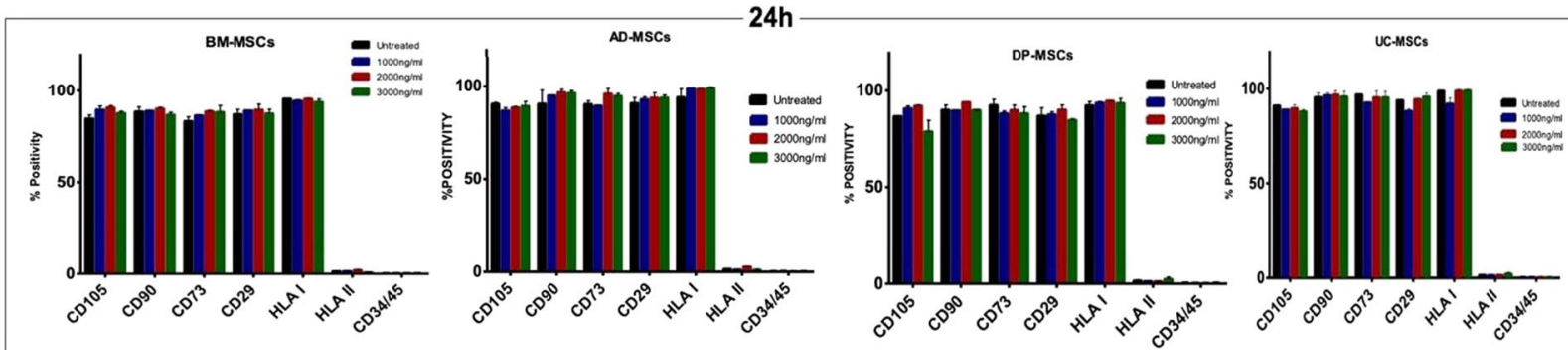

(d)
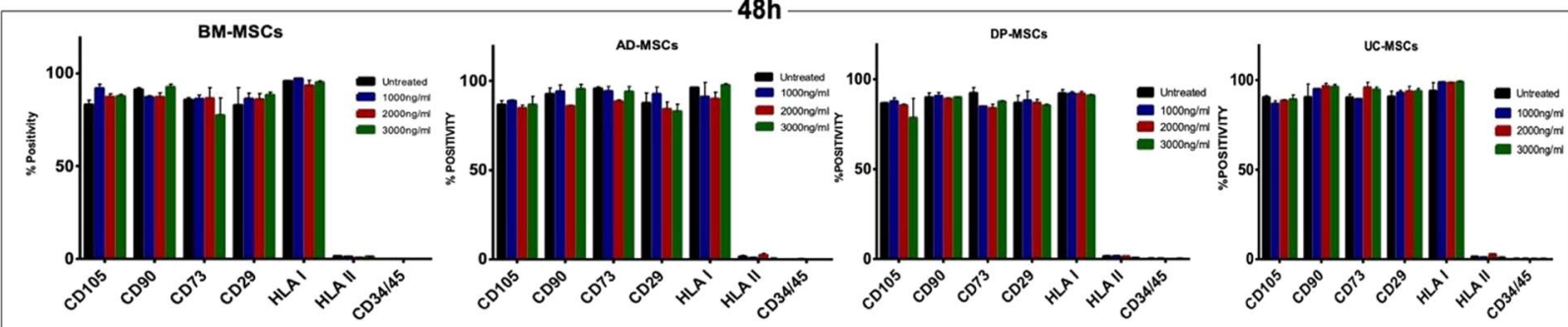

Fig. 2 Effect of Dex on cell proliferation and surface marker profiling of tissue specific hMSCs (a, b) A representative line graph shows cell growth capacity and (c, d) surface marker expression of tissue specific hMSCs upon pre-conditioning of different concentrations of Dex on tissue specific hMSCs. Positive marker CD 105, CD 90, CD 73, CD 29, and HLA-class I showed above 95\% positivity in all study groups and negative markers HLA-Class II and CD 34/45 did not show any expression at all the study groups. Data from three donors of each tissue-specific hMSCs

$1000 \mathrm{ng} / \mathrm{ml}$ for $48 \mathrm{~h}$. However, AD-MSCs did not show any significant change in percentage closed area but UC-MSCs showed maximum closed area at $3000 \mathrm{ng} /$ $\mathrm{ml}, 48 \mathrm{~h}$ (Fig. 3). In order to study the stemness of tissue specific hMSCs after preconditioning with different concentrations of Dex at different time points, we analyzed the signature gene expression of (Sox-2, Oct4, Nanog, Klf-4, and hTert) transcriptional and translational regulatory network in tissue specific hMSCs, compared to untreated hMSCs. In the treatment group, DP-MSCs and AD-MSCs displayed the highest expression level of stemness markers followed by UC-MSCs and BM-MSCs (Fig. 4). Moreover, Klf-4, Nanog and Sox-2 showed a strong upregulation in DP-MSCs and $\mathrm{AD}-\mathrm{MSCs}$ at $48 \mathrm{~h}$ of all different concentrations mostly at $2000 \mathrm{ng} / \mathrm{ml}$. However, telomerase gene (hTert) expression is similar in DP-MSCs and AD-MSCs but the lowest was observed in BM-MSCs and UC-MSCs. To further confirms the protein level expression was assessed at $48 \mathrm{~h}$ with all the dose concentrations via immunofluorescence staining for SOX-2, Nanog and OCT-4, (Additional file 1: Figs. S4, S5 and S6). 

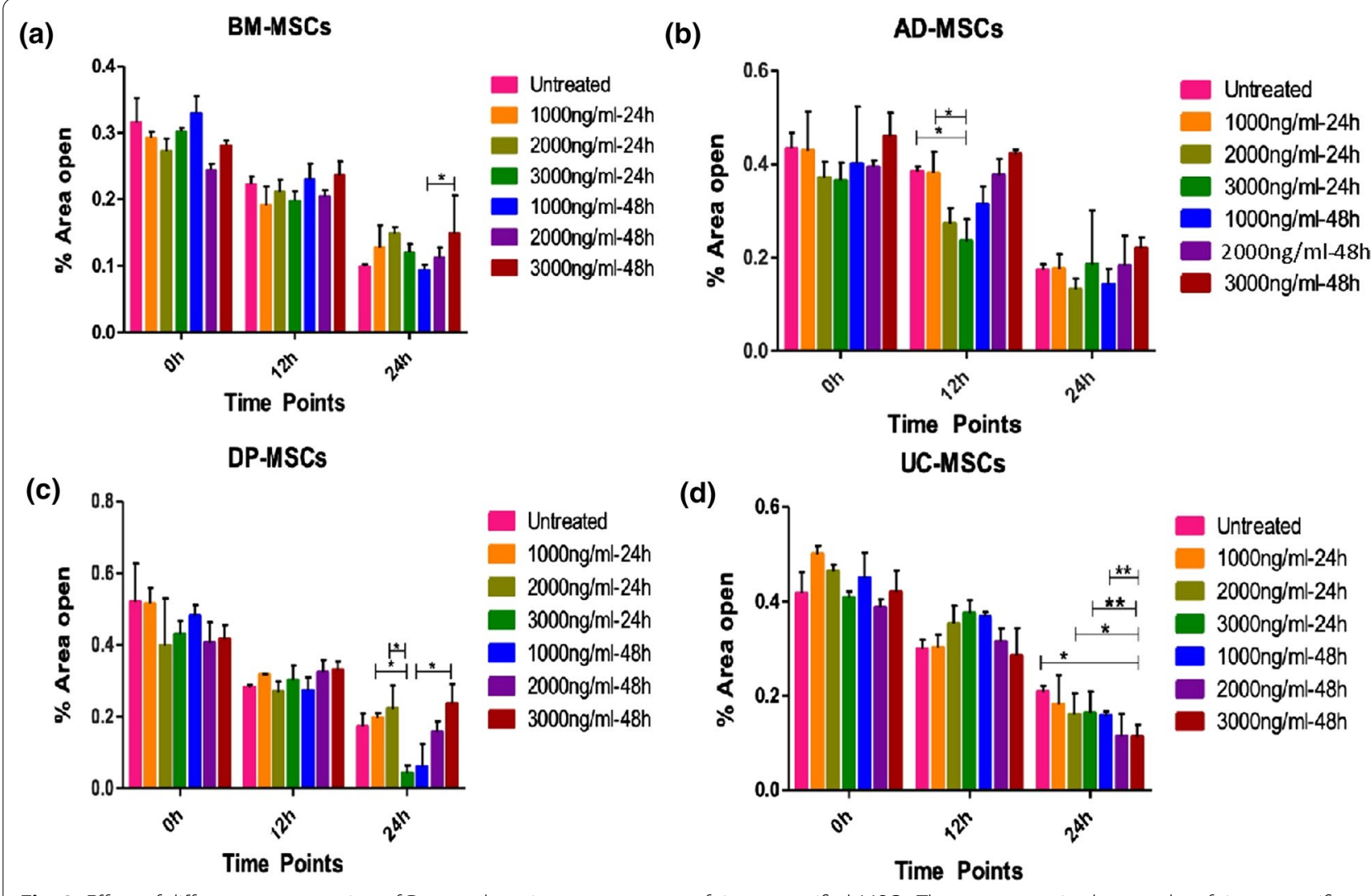

Fig. 3 Effect of different concentration of Dex on the migratory property of tissue specific hMSCs; The representative bar graphs of tissue specific hMSCs shows the scratch area at 0 h, 12 h, and $24 \mathrm{~h}$ after preconditioning with Dex in the dose and time-dependent manner. a A bar graph represents the \% area open from 0 to 24 h; BM-MSCs shows the maximum closed area at 1000 ng/ml 48 h, $\mathbf{b}$ AD-MSCs shows the almost similar response at all the dose concentration and time points; DP-MSCs showed significant closed area at $3000 \mathrm{ng} / \mathrm{ml}-24 \mathrm{~h}, 1000 \mathrm{ng} / \mathrm{ml} 48 \mathrm{~h}$ whereas UC-MSCs shows the response at $3000 \mathrm{ng} / \mathrm{ml} 48 \mathrm{~h}$ in all the study groups. Data from three donors and shown as mean $\pm \mathrm{SD} ;{ }^{* *} p<0.01,{ }^{*} p<0.05$

Effect of dexamethasone in the dose and time-dependent manner on immunomodulatory factors (IMF)

Dex is an anti-inflammatory steroid. Treating with either Dex or hMSCs for allogenic transplants are well established conventional lines of treatment; the effect of different concentrations of Dex on hMSCs immunomodulatory property. However, it is unknown. Therefore, to examine the effect of this interaction, BM-MSCs, ADMSCs, DP-MSCs and UC-MSCs were pre-conditioned with $1000 \mathrm{ng} / \mathrm{ml}, 2000 \mathrm{ng} / \mathrm{ml}$, and $3000 \mathrm{ng} / \mathrm{ml}$ of Dex for $24 \mathrm{~h}$ and $48 \mathrm{~h}$ and then, PGE-2, IDO and HLA-G1/G5 were assessed at both gene level and protein level.

\section{qRT-PCR assessment of PGE-2, IDO and HLA-G1/G5}

Relative expression of PGE-2 in tissue specific hMSCs; BM-MSCs showed a 15-fold change at $1000 \mathrm{ng} /$ $\mathrm{ml} \cong 3000 \mathrm{ng} / \mathrm{ml}$ at $24 \mathrm{~h}(p<0.001)$ an enhanced response towards Dex, whereas it did not show any response at $48 \mathrm{~h}$. Here, DP-MSCs ranked second among the other hMSCs, showed a nine-fold change at $2000 \mathrm{ng} /$ $\mathrm{ml} \cong 3000 \mathrm{ng} / \mathrm{ml}$ for $24 \mathrm{~h}(p<0.01)$, and no response at
48 h. However, AD-MSCs and UC-MSCs showed a minimal response to different concentrations and time points (Fig. 5a). The relative expression of IDO in tissue specific hMSCs was evaluated where BM-MSCs (80-fold change) $(p<0.001)$ showed highest fold change followed by ADMSCs (40-fold change) $(p<0.001)$ and DP-MSCs (fivefold change $(p<0.05)$ at $1000 \mathrm{ng} / \mathrm{ml}$ at $48 \mathrm{~h}, 3000 \mathrm{ng} / \mathrm{ml}$ for $48 \mathrm{~h}$ and $1000 \mathrm{ng} / \mathrm{ml}$ for $24 \mathrm{~h}$ respectively. However, UCMSCs did not showed any change in expression level of IDO at any preconditioning (Fig. 5b). Whereas, relative expression of panHLA-G in tissue specific hMSCs did not show any increase at the gene level in either of the tissue specific hMSCs upon pre-treatment with different concentrations of Dex and time points (Fig. 5c).

\section{Protein level assessment of PGE-2 and HLA-G1/G5}

Surface and intracellular expression of HLA-G assessment in Dex treated tissue specific hMSCs As HLA-G did not show any response at the gene level, therefore, $24 \mathrm{~h}$ was selected as optimum time point to assess surface and intracellular expression of HLA-G1 and HLA-G1/ 


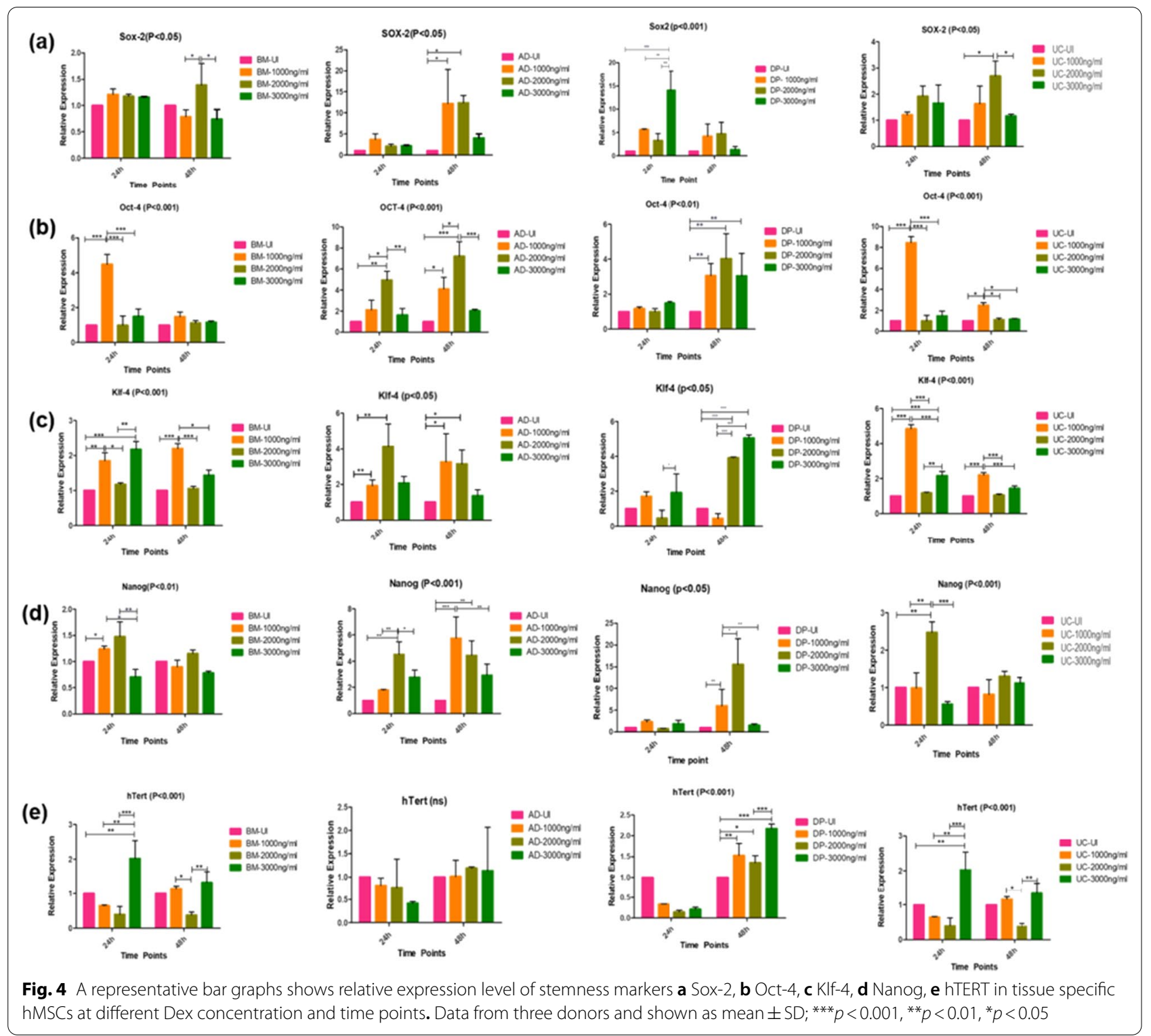

G5 at all studied Dex concentration. BM-MSC responded at $1000 \mathrm{ng} / \mathrm{ml}$ showing $30 \pm 10 \%$ cells positive for HLAG1, AD and DP-MSCs responded at $2000 \mathrm{ng} / \mathrm{ml}$ showing $25 \pm 10 \%$ positive expression whereas DP-MSCs and UCMSCs showed significant upregulation at $3000 \mathrm{ng} / \mathrm{ml}$ of Dex concentration (Fig. 6a, b).

To investigate the intracellular expression of HLAG1/G5 in tissue-specific hMSCs, immunofluorescence staining was performed. It was observed that BM-MSCs respond at $1000 \mathrm{ng} / \mathrm{ml}, \mathrm{AD}$ and DP-MSCs responded at $2000 \mathrm{ng} / \mathrm{ml}$ whereas DP-MSCs showed significant up-regulation at $3000 \mathrm{ng} / \mathrm{ml}$ and UC-MSCs shows significant up-regulation at $3000 \mathrm{ng} / \mathrm{ml}$. Altogether, BM-MSCs, AD-MSCs, and DP-MSCs showed a comparable response to Dex at $1000 \mathrm{ng} / \mathrm{ml}$ and $2000 \mathrm{ng} / \mathrm{ml}$. Whereas, UC-MSCs showed a significant response at $3000 \mathrm{ng} / \mathrm{ml}$ compared to untreated UCMSCs (Fig. 6c, d).

ELISA for assessment of PGE-2 and HLA-G5 in cell culture supernatant of treated and untreated tissue-specific hMSCs Tissue specific hMSCs were preconditioned with different Dex concentrations for $24 \mathrm{~h}$ as gene level studies showed significant upregulation of PGE-2 at this time point. The culture supernatant was collected and proceeded to perform ELISA for HLA-G5 and PGE-2. Where, BM-MSC responded at $1000 \mathrm{ng} / \mathrm{ml}$, AD-MSCs responded at $2000 \mathrm{ng} / \mathrm{ml}$ whereas $\mathrm{AD}$ and DP-MSCs 


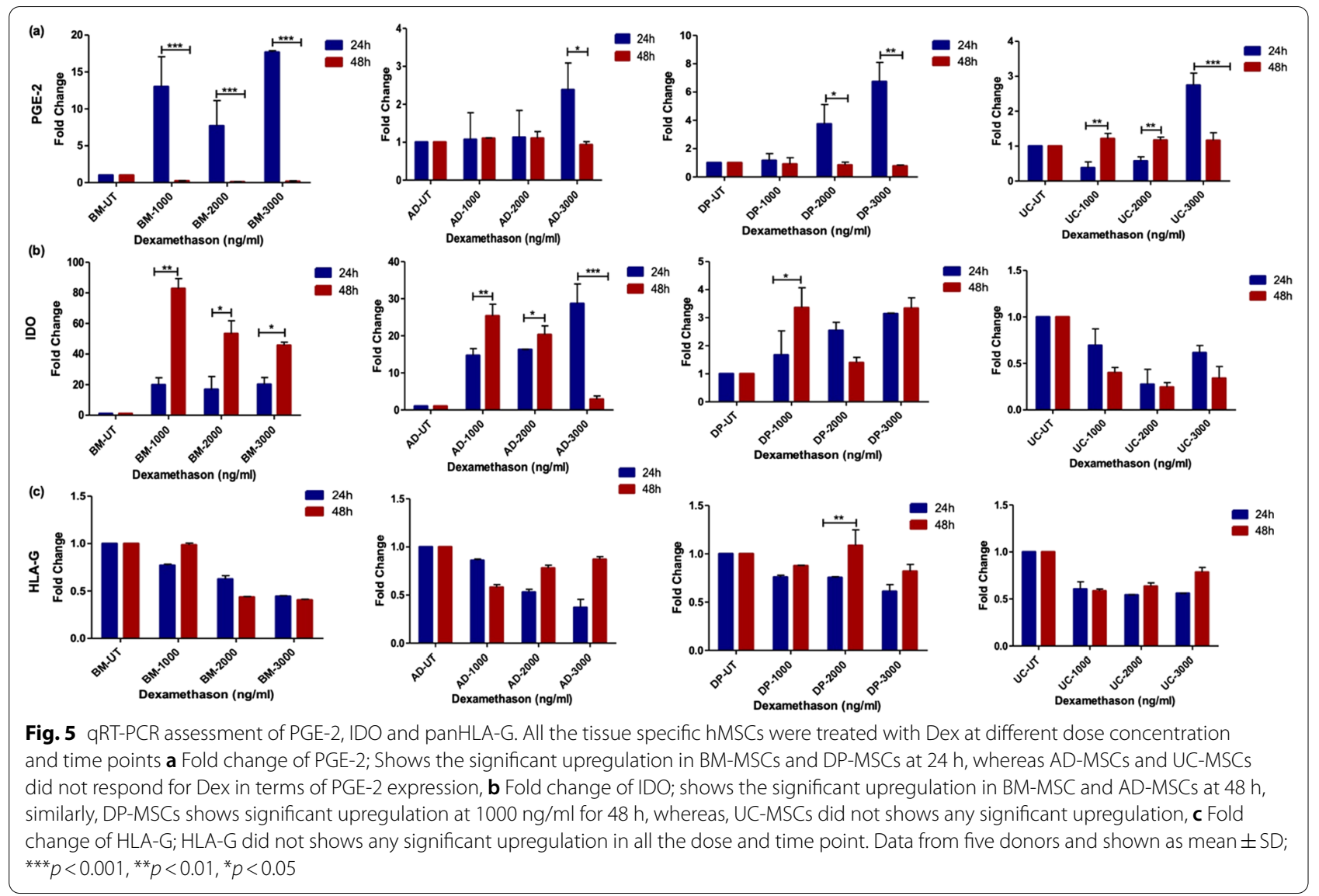

showed significant up-regulation at $3000 \mathrm{ng} / \mathrm{ml}$. However, UC-MSCs did not show significant secretion of soluble HLA-G (Fig. 6e and f). Moreover, BM-MSCs showed $210 \mathrm{pg} / \mathrm{ml}(p<0.001)$, DP-MSCs showed $150 \mathrm{pg} /$ $\mathrm{ml}(p<0.001)$, a significant amount of PGE-2 whereas AD-MSCs and UC-MSCs showed $50 \mathrm{pg} / \mathrm{ml}(p<0.05)$, of PGE-2 level at $2000 \mathrm{ng} / \mathrm{ml}$ of Dex treatment.

IDO activity in cultured supernatant of treated and untreated tissue-specific hMSCs IDO activity was determined by measuring the level of kynurenine in supernatant collected at $24 \mathrm{~h}$ and $48 \mathrm{~h}$ from untreated and Dex pre-conditioned tissue specific hMSCs. Preconditioned BM-MSCs and UC-MSCs shows significant amount of upregulation at $3000 \mathrm{ng} / \mathrm{ml}$ for $48 \mathrm{~h}$. On contrary, AD-MSCs, DP-MSCs did not shows any significant IDO activity after Dex pre-conditioning (Fig. 7).

\section{Differential immune-suppressive ability of tissue specific hMSCs}

The immuno-suppressive capacity of these hMSCs was assessed under untreated and pre-conditioning with $3000 \mathrm{ng} / \mathrm{ml}$ for $24 \mathrm{~h}$ and $48 \mathrm{~h}$ via one-way mixed lymphocyte reaction. The culture condition was selected as all the tissue specific hMSCs showed significant response. The inhibition of proliferation of peripheral blood mononuclear cells (PBMCs) was observed in each hMSCs groups, against the positive control i.e., PHA activated PBMCs (PBMCs*) (Fig. 8). The percentage decrease of PBMCs suppression was calculated (Table 2). It was observed that untreated BM-MSCs showed 44.5\% decrease whereas pre-conditioned BM-MSCs showed similar decrease i.e., 46.32\%. AD-MSCs showed similar response as BM-MSCs i.e., untreated group showed 41.11\% decrease and pre-conditioned group showed 51.03\% decrease. Unlike BM-MSC and AD-MSCs, DPMSCs showed significant decrease at $3000 \mathrm{ng} / \mathrm{ml}$ preconditioning for $24 \mathrm{~h}$ and $48 \mathrm{~h}$, i.e., $60.94 \%$ and $62.41 \%$ decrease respectively. Similarly, UC-MSCs showed significant decrease at $3000 \mathrm{ng} /$ for $48 \mathrm{~h}$ preconditioning, i.e., $55.64 \%$. Overall, DP-MSCs and UC-MSCs showed significant immune suppression as compared to AD-MSCs and BM-MSCs.

\section{Discussion}

Mesenchymal stem cells are multipotent, non-hematopoietic cells with different tissue origins. They have become a promising candidate for the treatment of many 


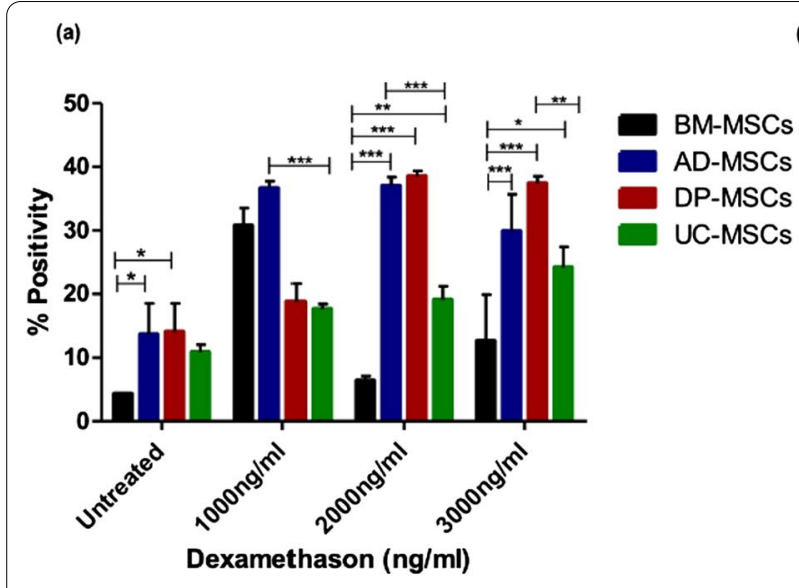

(b)
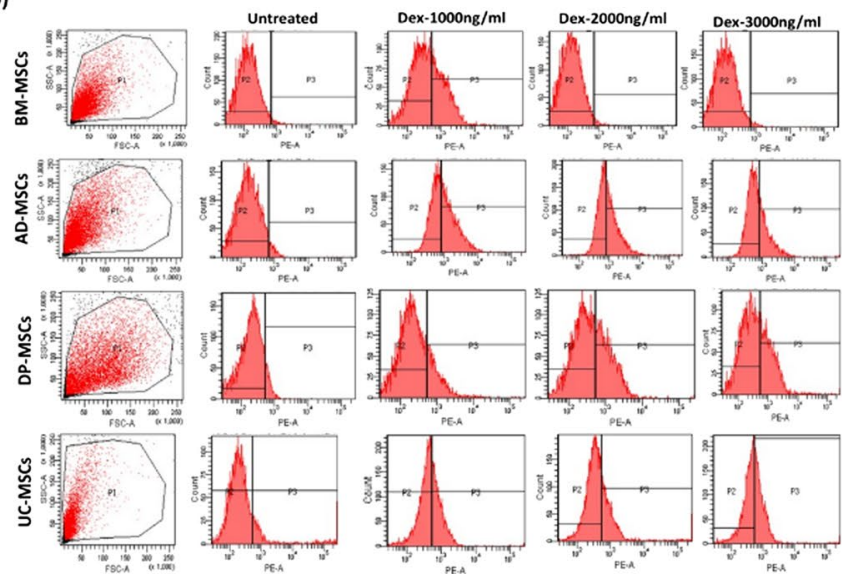

(d) Untreated

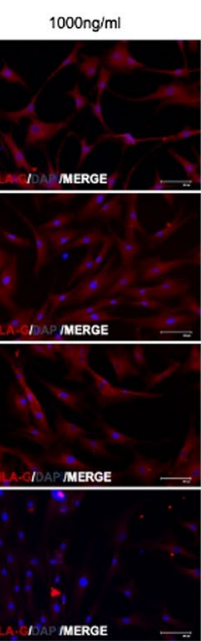

$2000 \mathrm{ng} / \mathrm{ml}$

$3000 \mathrm{ng} / \mathrm{ml}$
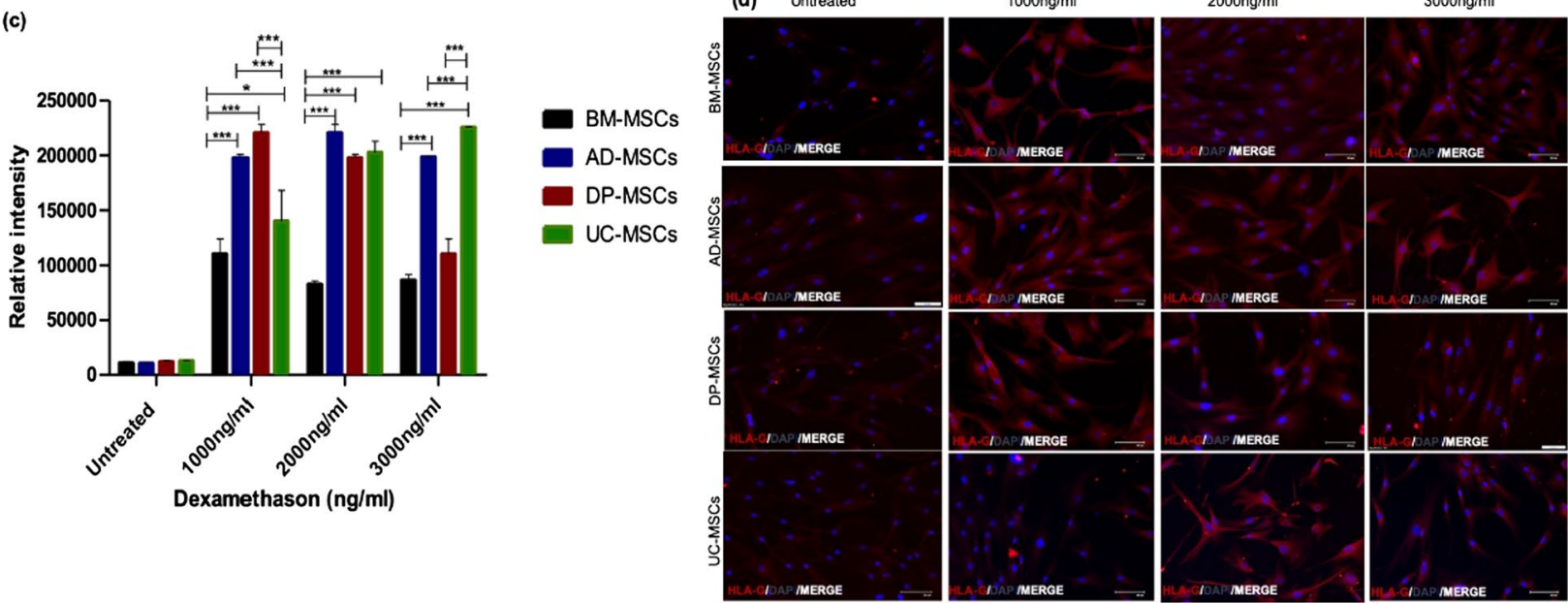

(e)

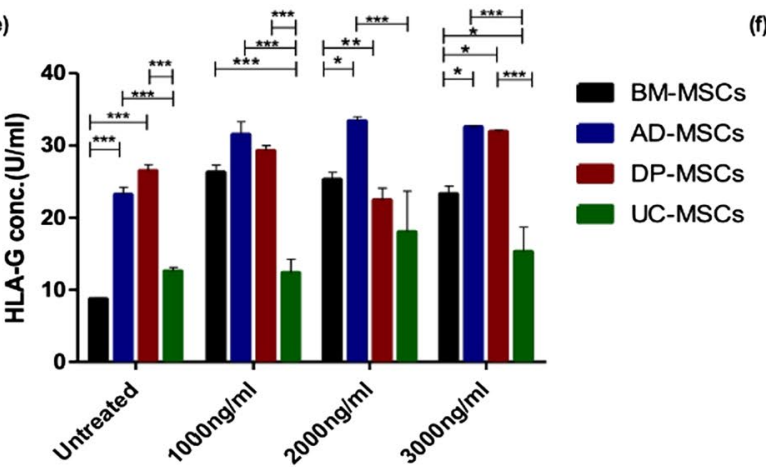

Study groups
BM-MSCs

AD-MSCs

UC-MSCs
DP-MSCs

Fig. 6 Protein level assessment of HLA-G1/G5 and PGE-2 after $24 \mathrm{~h}$ of preconditioning: a A bar graph represents the \% Positivity of BM-MSCS responds at $1000 \mathrm{ng} / \mathrm{ml}$, AD and DP-MSCs responds at $2000 \mathrm{ng} / \mathrm{ml}$ whereas DP-MSCs shows significant upregulation at $3000 \mathrm{ng} / \mathrm{ml}$ and UC-MSCs shows significant upregulation at $3000 \mathrm{ng} / \mathrm{ml}$, b Pictographs represents the histograms for tissue specific hMSCs using BD FACs Diva ${ }^{\mathrm{TM}}$ software. Intracellular expression of HLA-G in tissue specific hMSCs; c and $\mathbf{d}$ A pictograph and bar graph represent the relative intensity of intracellular HLA-G expression in tissue specific hMSCs. ELISA data for soluble HLA-G5 and PGE-2 in cell culture supernatant at $24 \mathrm{~h}$ of Dex preconditioning; e A bar graph represents the BM-MSC responds at $1000 \mathrm{ng} / \mathrm{ml}$, AD-MSCs responds at $2000 \mathrm{ng} / \mathrm{ml}$ whereas AD and DP-MSCs showed significant upregulation at $3000 \mathrm{ng} / \mathrm{ml}$ and UC-MSCs did not showed significant secretion of sHLA-G, $\mathbf{f}$ Bar graph represents that BM-MSCs shows highest expression level at $1000 \mathrm{ng} / \mathrm{ml}$, AD-MSCs at $3000 \mathrm{ng} / \mathrm{ml}$, DP-MSCs at $3000 \mathrm{ng} / \mathrm{ml}$ whereas UC-MSCs showed significant upregulation at $1000 \mathrm{ng} / \mathrm{ml}$. Data from three donors in duplicates and shown as mean $\pm S D ;{ }^{* *} p<0.001,{ }^{* *} p<0.01,{ }^{*} p<0.05$. Scale bar $100 \mu m$ 


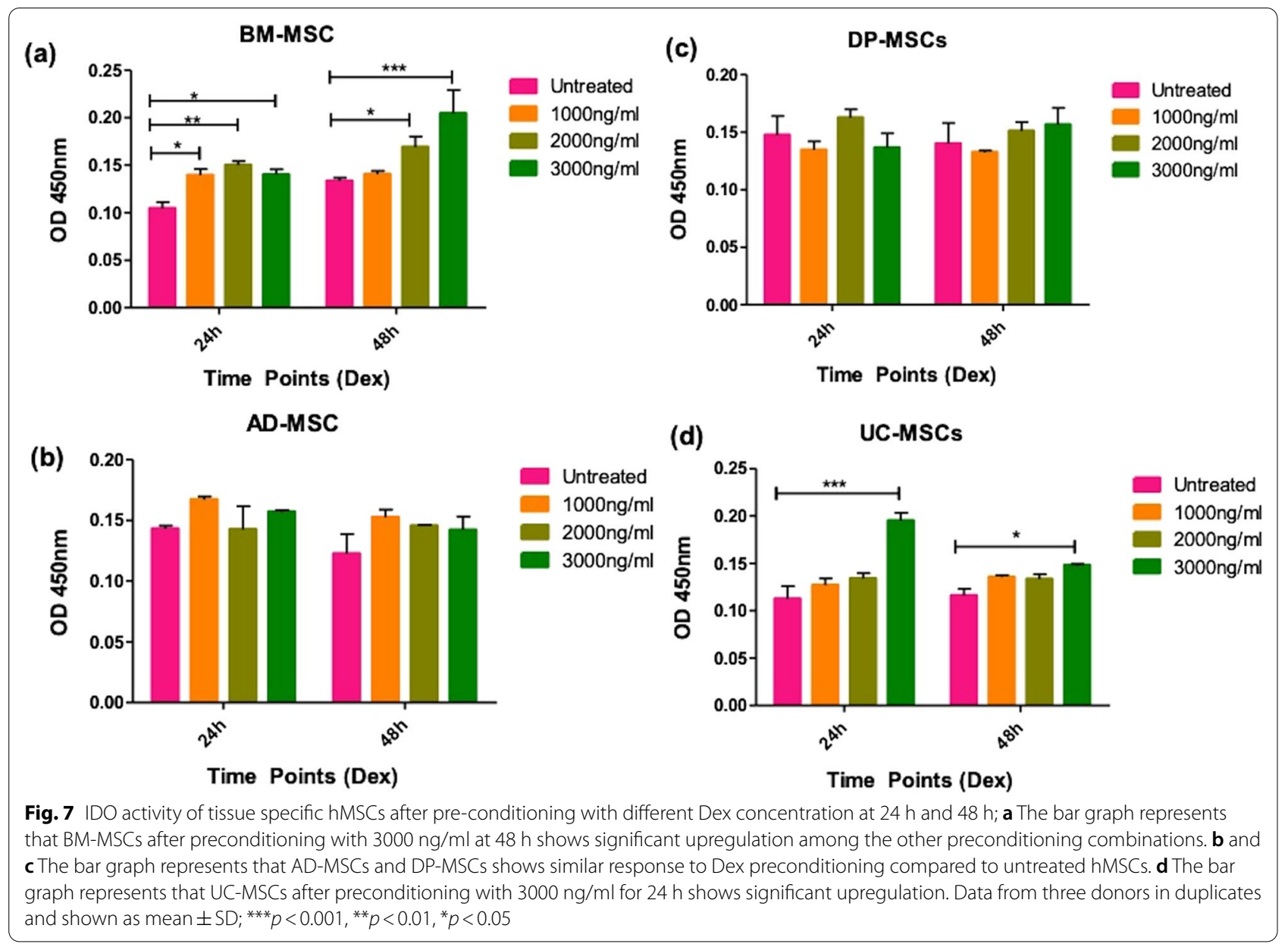

autoimmune and allogeneic transplant conditions due to their immunoregulatory, anti-inflammatory, and proregenerative properties. hMSCs can be isolated from different tissue sources such as adipose, umbilical cord, dental pulp, bone marrow, etc. and depending upon the tissue origin they display varying features in vitro and in vivo $[30,31]$. So far, BM-MSCs and AD-MSCs are most frequently being used for clinical trials involving degenerative and autoimmune diseases. Till now, it has been observed that all the tissue specific hMSCs display similar basic characteristic properties but it is still unclear which tissue source has a better functionality at the time of inflammation. Inflammatory microenvironments could also produce a rise in hMSCs immunogenicity, which might pose adverse safety and efficacy implications for their allogeneic use [32, 33]. Therefore, maintenance of low immunogenicity even under inflammatory stress is an important factor to consider for prospecting safe hMSCs' allogeneic transplantation. However, the need of the hour is to have a different approach to precondition the hMSCs for inflammatory microenvironment. Several clinical studies have shown that various immunosuppressive drugs and hMSCs are being co-administered as a line of treatment for autoimmune diseases, due to which few of hMSCs properties are being compromised such as homing and cytoskeleton changes [34]. To the best of our knowledge, the present study is the first report to compare the effect of Dex pre-treatment on tissue specific hMSCs for its therapeutic potential, by evaluating a range of their basic characteristics. Herein, we demonstrated that this pretreatment approach is highly effective in augmenting the immunotherapeutic function of hMSCs in terms of immunomodulation. In vivo, the concentration of glucocorticoids is markedly upregulated in maternal plasma and amniotic fluid near the fetus, during the pre-term or expected time of parturition [18]. They promote HLA-G expression and Th2 cytokine secretion profile, thereby preventing the semi-allogeneic fetus from allograft rejection by the maternal immune system [35]. To mimic this condition, we focused on examining the direct effect of Dex on hMSCs, without interfering with hMSCs native properties and offering an improvised product for therapeutic purposes. In this regard, a time-dependent study 
(a)

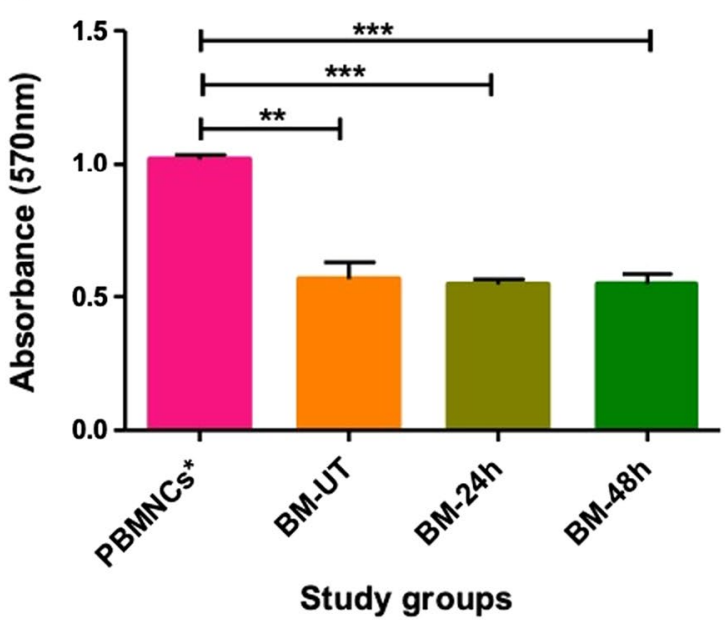

(b)

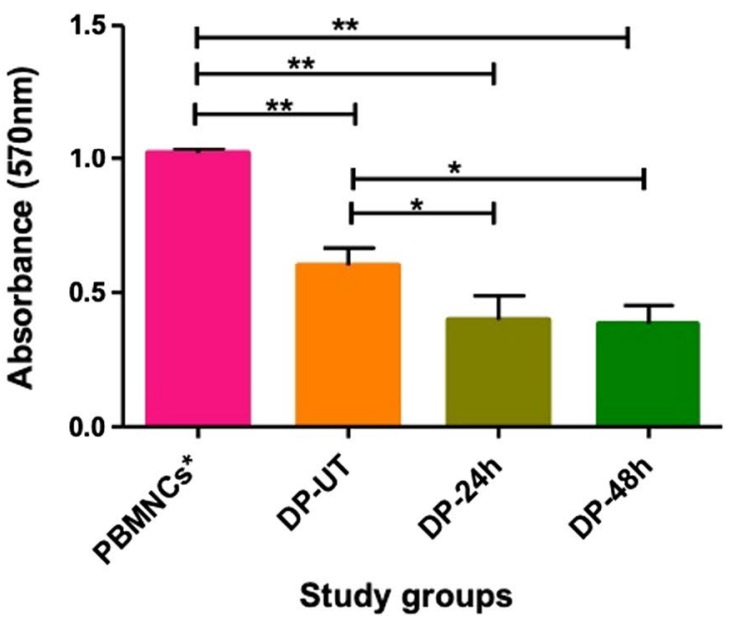

(c)

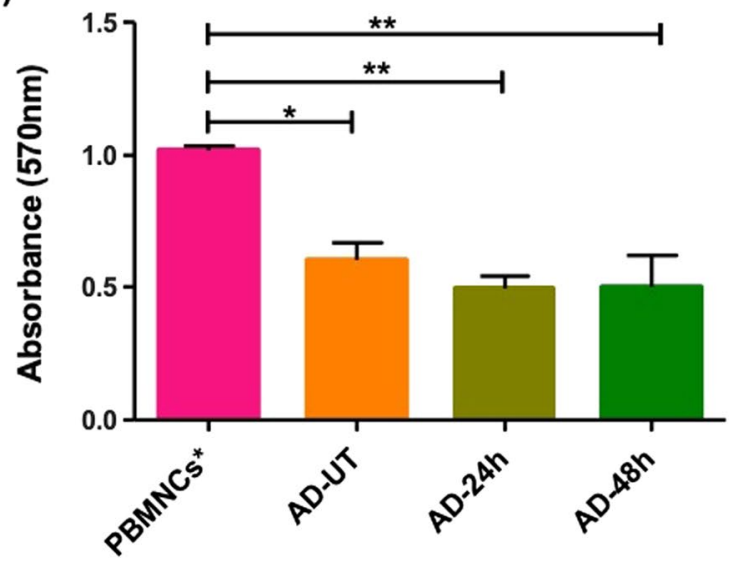

Study groups

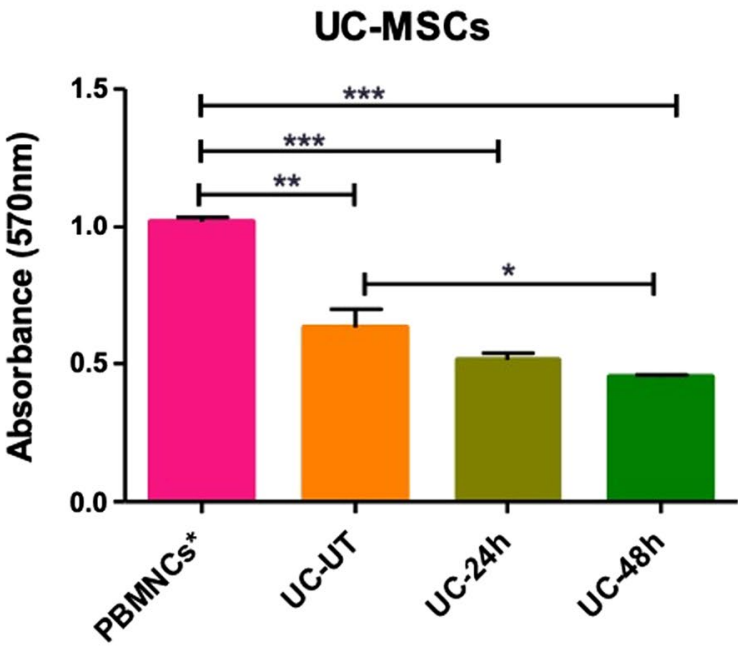

Study groups

Fig. 8 Immunosuppressive activity of tissue-specific hMSCs in allogeneic condition after pre and post-preconditioning with Dex; a and $\mathbf{c}$ The bar graph represents that $48 \mathrm{~h}$ Dex-pretreated BM-MSCs and AD-MSCs shows the significant ability to inhibit the PBMCs proliferation with respect to activated PBMCs, $\mathbf{b}$ and $\mathbf{d}$ the bar graph represents that $48 \mathrm{~h}$ Dex-pretreated DP-MSCs and UC-MSCs shows significant inhibition compared to untreated hMSCs and activated hMSCs. Data from three donors in duplicates and shown as mean \pm SD; ${ }^{* * *} p<0.001,{ }^{* *} p<0.01,{ }^{*} p<0.05$. Note: PBMCs* (PHA activated PBMCs)

of different concentrations of Dex was performed to understand its effects on immunosuppressive properties [35]. It was observed that Dex did not show any effect on the cellular morphology at either of the concentrations $(1000,2000,3000 \mathrm{ng} / \mathrm{ml})$ and is non-cytotoxic to all the tissue specific hMSCs. Cody et al.reported the differential cytotoxicity of various corticosteroids on AD-MSCs, with Dex showing the least toxic effects at $4 \mathrm{mg} / \mathrm{ml}$ for $24 \mathrm{~h}$ as compared to other tested drugs [36]. Whereas, in the present study maximum of $3000 \mathrm{ng} / \mathrm{ml}$ for $48 \mathrm{~h}$ was studied and showed no toxicity.
It was observed that Dex treatment did not alter their surface marker profile, as per the criteria set by ISCT guidelines, along with metabolic activity. Notably, In Hwan song and Seong Yong reported that Dex treatment for 3 weeks influences the proliferation rate of hMSCs in long term culture by suppression of apoptosis [37]. Whereas, another study highlighted that $10^{-8} \mathrm{M}$ dose of Dex maintains proliferative potential, stemness and non-differential potential of cells [22]. As a matter of fact, Dex is known to be an important inducer for osteogenic and Adipogenic lineages [20]. In the present 
Table 2 Percentage decrease in the proliferation of immune cells

\begin{tabular}{llll}
\hline S. Nos & Culture conditions & $\begin{array}{l}\text { Average OD } \\
(\mathbf{n}=\mathbf{5})\end{array}$ & \% Decrease \\
\hline 1 & PBMCs & 1.0195 & \\
2 & MLR-BM-UT & 0.5655 & 44.5 \\
3 & MLR-BM-24 & 0.5455 & 47.79 \\
4 & MLR-BM-48 h & 0.547 & 46.32 \\
5 & MLR-AD-UT & 0.600 & 41.11 \\
6 & MLR-AD-24 & 0.4945 & 51.52 \\
7 & MLR-AD-48 h & 0.499 & 51.03 \\
8 & MLR-DP-UT & 0.612 & 37.34 \\
9 & MLR-DP-24 & 0.398 & 60.94 \\
10 & MLR-DP-48 h & 0.383 & 62.41 \\
11 & MLR-UC-UT & 0.630 & 38.17 \\
12 & MLR-UC-24 & 0.513 & 49.65 \\
13 & MLR-UC-48 h & 0.452 & 55.64 \\
\hline
\end{tabular}

study, it was observed that Dex can elicit stemness markers in a dose-response manner. Whereas, higher the dose of Dex can treat them towards differentiation. However, it is favorable to use the low concentration of Dex to enhance stemness properties of hMSCs. Moreover, this study has allowed to maximize the stemness of tissue specific hMSCs at low concentration of Dex without any maximum manipulation.

Interestingly, it is the first report where scratch assay showed that Dex preconditioning has upregulated the migratory property of tissues specific hMSCs. On contrary, Schneider et al. reported that treatment of hMSCs from human term chorionic membranes with $10 \mu \mathrm{M}$ Dex for $24 \mathrm{~h}$ resulted in elevated cells membrane activity (Focal adhesion points), however longer treatment (day 7) with Dex impaired the migratory speed and impacting the homing of hMSCs [32]. However, the upregulated migration may be attributed due to higher expression of PGE-2 after Dex preconditioning. Lu et al. [38] study indicates that PGE-2 facilitates hMSCs migration and their findings suggest that EP2 prostanoid receptor encourages hMSCs migration through activation of FAK and ERK1/2 pathways. These data suggest that Dex may have various effects on the actin dynamics of hMSCs, with possible effects on its migratory activity $[32,38]$.

Taken together, robust stemness and enhanced migratory property indicates the higher regenerative potential, better survival in vivo, maintaining the primitive stage of hMSCs, and homing of tissue specific hMSCs. Since immunoregulatory mechanisms can vary between different species and hMSCs tissue sources, a variety of factors could participate in the hMSCs immunosuppression mechanisms. Reported findings suggest that IL-10 and TGF- $\beta 1$ may not have a major role in BM-MSC immunoregulation [39]. However, both cell-cell contact and paracrine signaling mechanisms are implied in the immunoregulatory functions of hMSCs. Paracrine signaling and immunomodulation mechanisms are mainly governed by various molecules such as IDO, iNOS, IL-6, and COX-2, and HLA-G1/G5 eliciting different mechanisms on immune cells [39]. Therefore, we again for the first time have evaluated the time-dependent, tissue specific hMSCs response to different concentrations of Dex, evaluated by immunomodulatory genes PGE-2, IDO and HLA-G. Prostaglandins are small molecule derivatives of arachidonic acid (AA), has a property to furnish toward immune pathology and creates a potential target for immunomodulation. Notably, the effect of PGE-2 in most cases is exerted in combination with other immunosuppressive molecules [38]. Alongside its role in inflammatory response, PGE-2 is also involved in proliferation and migration in several cell types. Therefore, we looked for the gene expression level of PGE-2 in BM-MSCs, AD-MSCs, DP-MSCs, and UC-MSCs after pre-treatment with Dex $(1000,2000,3000 \mathrm{ng} / \mathrm{ml})$ at different time points. Interestingly, PGE-2 expression was significantly high in BM-MSCs and DP-MSCs at $1000 \mathrm{ng} /$ $\mathrm{ml}$ at $24 \mathrm{~h}$. Whereas, AD-MSCs and UC-MSCs did not show any significant response to Dex concentrations and time points. Tryptophan depleting enzyme indoleamine-2,3-dioxygenase (IDO) is considered as one of the major molecules for mediating hMSCs immune suppression. Distinctively, IDO is the first and rate-limiting enzyme involved in degradation of tryptophan down the kynurenine pathway and is mostly expressed in antigen presenting cells (APCs) in response to IFN-gamma [40]. However, IDO is also majorly expressed in the placental cells and is responsible for fetal-maternal tolerance [41]. Herein, we sought for the effect of Dex preconditioning upon IDO expression in hMSCs at gene and protein level. It was observed that at gene level BM-MSCs and AD-MSCs showed the significant upregulation of IDO at $1000 \mathrm{ng} / \mathrm{ml}$ for $24 \mathrm{~h}$. Whereas, assessment of IDO activity in conditioned media for BM-MSCs showed dose and time dependent upregulation, i.e., $3000 \mathrm{ng} / \mathrm{ml}$ for $48 \mathrm{~h}$ showed the highest IDO activity. Moreover, to the best of our knowledge this is the novel study, where we showed the upregulation of IDO after Dex preconditioning alone. However, other groups have used glucocorticoid steroids such as budesonide for augmenting IDO expression and activity in hMSCs [42].

Prior to this study, there have been only few reports about the effect of glucocorticoids (GCs) on the expression of HLA-G, and to the best of our knowledge, there are no reports on the association of Dex 
effect on hMSCs and HLA-G. Therefore, we evaluated the gene and protein HLA-G expression in tissue specific hMSCs and observed that at gene level there is no significant difference. In addition to this, the surface expression of HLA-G1, intracellular expression of HLA-G1/G5, and soluble HLA-G5 were investigated with all concentrations $(1000,2000,3000 \mathrm{ng} / \mathrm{ml})$ of Dex at $24 \mathrm{~h}$. We observed that BM-MSCs showed significant HLA-G1, G1/G5, and G5 expression at $1000 \mathrm{ng} /$ $\mathrm{ml}, \mathrm{AD}$, and DP-MSCs showed the highest expression of surface and intracellular HLA-G at $2000 \mathrm{ng} / \mathrm{ml}$ whereas soluble HLA-G is highly expressed at $3000 \mathrm{ng} /$ $\mathrm{ml}$. Among all the tissue specific hMSCs, UC-MSCs showed the lowest amount of upregulation of all forms of HLA-G. However, the variation in the response of tissue specific hMSCs is might be due to higher basal expression level of HLA-G in maternal associated tissue than the other tissue specific hMSCs. This indicates that UC-MSCs showed minimal response to Dex whereas BM-MSCs, AD-MSCs, and DP-MSCs showed the highest expression level in a dose-dependent manner. Moreau et al. showed that Dex and hydrocortisone up-regulate HLA-G in first-trimester trophoblast cells at the gene level [43-45]. Altogether we found that tissue specific hMSCs have differential response towards the dose and time point of Dex. Further we performed the functionality assessment (MLR) to understand the response of Dex preconditioned hMSCs. Interestingly, Michelo et al. reported that Dex did not hamper the immunosuppressive ability of hMSCs, on the other hand, it augmented the inhibitory effect of hMSCs via STAT5 phosphorylation, CD69 surface expression, and IFN- $\gamma$ production. This urges that hMSCs and Dex are using the corresponding mode of action for suppression $[44,46]$. However, it was observed that UC-MSCs and DP-MSCs showed the maximum amount of suppression followed by AD-MSCs and BM-MSCs.

Taken together, Dex preconditioning in tissue specific hMSCs showed upregulation in stemness and migratory property. In addition, it augments the therapeutic capacity, evidently via enhanced functional characteristics as well as immunosuppressive ability. However, higher concentration and shorter treatment duration $(3000 \mathrm{ng} / \mathrm{ml} / 24 \mathrm{~h})$, low concentration for a longer treatment duration $(1000 \mathrm{ng} / \mathrm{ml} / 48 \mathrm{~h})$ approach was seen to be an ideal setting to augment or upregulate the immunomodulatory response of these tissue specific hMSCs. Clinical application of this approach can simply involve exposure of UC/DP-MSCs to Dex for a shorter duration, before cell infusion.

Furthermore, preconditioning of hMSCs could be an interesting approach to maximize the systemic immunomodulatory effects of hMSCs. Enhancing the potency of a single hMSCs warrants the fewer hMSCs to be administered to achieve the similar therapeutic effect and allows them to endeavor the significant impact on its microenvironment.

\section{Conclusions}

Our results provide evidence that low dose preconditioning for the longer time period and high dose preconditioning for a shorter time period of tissue specific hMSCs with dexamethasone maintains the native hMSCs properties viz enhancing the stemness, migration and immunomodulatory property. However, it should be noted that each tissue specific hMSCs respond differentially to Dex and elicit immunomodulatory factors, possibly impacting the success of stem cell treatment. Interestingly, as compared to other wide range of corticosteroids the Dex preconditioning did not significantly impacted the viability, metabolic activity, and morphology of hMSCs. Due to distinct mechanisms of action, the preconditioning of hMSCs with Dex may offer a promising therapeutic regimen for the enhancement of solid graft survival, potentially for the treatment of GvHD and now COVID-19. Therefore, our in vitro study demonstrated that tissue specific hMSCs responds in a dose-dependent manner and have no negative effect on hMSCs. Finally, for the purposes of a future clinical application, mechanistic pathways and the in vivo assessment are necessary to study the potential role of hMSCs for the treatment of various inflammatory disorders.

\section{Abbreviations}

Dex: Dexamethasone; hMSCs: Human mesenchymal stem cells; BM: Bone marrow; AD: Adipose tissue; DP: Dental pulp; UC: Umbilical cord; GvHD: Graft versus host disease; ISD: Immunosuppressive drugs; CsA: Cyclosporine; IMPDH: Mycophenolate mofetil dehydrogenase; COX: Cyclooxygenase; PGE-2: Prostaglandin-2; ESC: Embryonic stem cells; OD: Optical density; PBMCs: Peripheral blood mononuclear cells; PHA: Phytohemagglutinin A; GC: Glucocorticoids.

\section{Supplementary Information}

The online version contains supplementary material available at https://doi. org/10.1186/s12861-021-00246-4.

Additional file 1. Supplementary Figure 1: A representative pictograph shows trilineage differentiation of tissue specific hMSCs (a) A panel shows osteocyte differentiation which is confirmed by alizarin red staining, (b) Adipocyte's differentiation shows positivity for oil red "o" staining. (c) Chondrocyte's differentiation shows positivity for Alcian blue staining. Scale bar $50 \mu \mathrm{m}$. Supplementary Figure 2: A representative pictograph showing the morphology of tissue specific hMSCs upon pre-conditioning of different Dex concentrations at $24 \mathrm{~h} \& 48 \mathrm{~h}$. Scale bar $100 \mu \mathrm{m}$. Supplementary Figure 3: A representative pictograph shows scratch assay in tissue specific hMSCs (a-d) Scratch at $0 \mathrm{~h}$ represents the initial day whereas closure of the area was taken at $12 \mathrm{~h}$ and $24 \mathrm{~h}$ and $\%$ open area was calculated. Scale bar $100 \mu \mathrm{m}$. Supplementary Figure 4: (a-d) Representative images shows intracellular SOX-2 expression level in BM-MSCs, whereas (e) Bar graph represent the relative intensity for SOX-2 expression after 
pre-conditioning with different Dex concentrations at $48 \mathrm{~h}$, where 2000 $\mathrm{ng} / \mathrm{ml}$ shows the significant expression level. (f-i) Representative images shows intracellular SOX-2 expression level in AD-MSCs, (j) Bar graph represent the relative intensity for SOX-2 expression after pre-conditioning with different Dex concentrations at $48 \mathrm{~h}$ and shows dose-dependent increase in expression level, $(k-n)$ Representative images shows intracellular SOX-2 expression level in DP-MSCs, whereas (o) Bar graph represent the relative intensity for SOX-2 expression after pre-conditioning with different Dex concentrations at $48 \mathrm{~h},(\mathrm{p}-\mathrm{s})$ Representative images shows intracellular SOX-2 expression level in UC-MSCs, whereas (e) Bar graph represent the relative intensity for $\mathrm{SOX}-2$ expression after pre-conditioning with different Dex concentrations at $48 \mathrm{~h}$, shows dose-dependent increase in expression level. Scale bar $200 \mu \mathrm{m}$. Supplementary Figure 5: (a-d) Representative images shows intracellular NANOG expression level in BM-MSCs,whereas (e) Bar graph represent the relative intensity for NANOG expression after pre-conditioning with different Dex concentrations at $48 \mathrm{~h}$, where $1000 \mathrm{ng} / \mathrm{ml}$ shows the significant expression level. (f-i) Representative images shows intracellular NANOG expression level in AD-MSCs, (j) Bar graph represent the relative intensity for NANOG expression after preconditioning with different Dex concentrations at $48 \mathrm{~h}$ and where 1000 $\mathrm{ng} / \mathrm{ml}$ shows the significant expression level, $(\mathrm{k}-\mathrm{n})$ Representative images shows intracellular NANOG expression level in DP-MSCs, whereas (o) Bar graph represent the relative intensity for NANOG expression after preconditioning with different Dex concentrations at $48 \mathrm{~h}$, where $3000 \mathrm{ng} / \mathrm{ml}$ shows the significant expression level $(\mathrm{p}-\mathrm{s})$ Representative images shows intracellular NANOG expression level in UC-MSCs, whereas (e) Bar graph represent the relative intensity for NANOG expression after pre-conditioning with different Dex concentrations at $48 \mathrm{~h}$, shows dose-dependent increase in expression level. Scale bar $200 \mu \mathrm{m}$. Supplementary Figure 6 (a-d) Representative images shows intracellular OCT-4 expression level in BM-MSCs, whereas (e) Bar graph represent the relative intensity for OCT-4 expression after pre-conditioning with different Dex concentrations at 48 $\mathrm{h}$, where $3000 \mathrm{ng} / \mathrm{ml}$ shows the significant expression level. (f-i) Representative images shows intracellular OCT-4 expression level in AD-MSCs, (j) Bar graph represent the relative intensity for OCT-4 expression after pre-conditioning with different Dex concentrations at $48 \mathrm{~h}$ and where $3000 \mathrm{ng} / \mathrm{ml}$ shows the significant expression level, $(\mathrm{k}-\mathrm{n})$ Representative images shows intracellular OCT-4 expression level in DP-MSCs, whereas (o) Bar graph represent the relative intensity for OCT-4 expression after preconditioning with different Dex concentrations at $48 \mathrm{~h}$, where $2000 \mathrm{ng} / \mathrm{ml}$ shows the significant expression level $(p-s)$ Representative images shows intracellular OCT-4 expression level in UC-MSCs, whereas (e) Bar graph represent the relative intensity for OCT-4 expression after pre-conditioning with different Dex concentrations at $48 \mathrm{~h}$, where $1000 \mathrm{ng} / \mathrm{ml}$ shows the significant expression level. Scale bar $200 \mu \mathrm{m}$.

\section{Acknowledgements}

We are grateful for the support rendered by Ms. Zoya Mann and Ms. Jyoti Das towards Cell Culture and ELISA respectively. We would like to thank Mr. E Pranshu Rao and Ms. Suchi Gupta for helping us with Microscopy and trilineage differentiation studies respectively. We thank Professor Anis Feki, Geneva University Hospitals, Switzerland for providing us IHF cell line.

\section{Authors' contributions}

SR designed and performed the experiments, analyzed the results, and wrote the paper. VD provided umbilical cords for the study and analyzed the results. SM conceived the research, critically analyzed the results, wrote the paper. All authors have read and agreed to the final version of the manuscript. All authors read and approved the final manuscript.

\section{Funding}

This work was funded by the Department of Science and Technology (EMR/2017/000229), India. We are also grateful for the support of the All-India Institute of Medical Sciences, New Delhi.

\section{Availability of data and materials}

Please contact the corresponding author for data requests.

\section{Declaration}

\section{Ethics approval and consent to participate}

Mesenchymal Stromal Cells and Peripheral Blood used in this study were isolated from healthy donors with written consent after obtaining ethical clearance from Institutional Committee for Stem Cell research (ICSCR), and Institutional Ethical Clearance (IEC), AllMS, New Delhi.

\section{Consent for publication}

Not applicable.

\section{Competing interests}

The authors declare no competing interest.

\section{Author details}

'Stem Cell Facility, All India Institute of Medical Science, New Delhi, India. ${ }^{2}$ Department of Obstetrics and Gynecology, All India Institute of Medical Science, New Delhi, India.

Received: 20 May 2021 Accepted: 19 October 2021

Published online: 04 November 2021

\section{References}

1. Fuchs EJ. Transplantation tolerance: from theory to clinic. Immunol Rev. 2014;258(1):64-79. https://doi.org/10.1111/imr.12154.

2. Gummert JF, Ikonen T, Morris RE. Newer immunosuppressive drugs: a review. J Am Soc Nephrol. 1999;10(6):1366-80.

3. Wu JC. Mycophenolate mofetil: molecular mechanisms of action. Perspect Drug Discov Des. 1994;2:185-204. https://doi.org/10.1191/09612 03305lu2109oa.

4. Cato $A C B$, Wade E. Molecular mechanisms of anti-inflammatory action of glucocorticoids. BioEssays. 1996;18(5):371-8. https://doi.org/10.1002/bies. 950180507.

5. Vitale $\mathrm{C}$, et al. The corticosteroid-induced inhibitory effect on NK cell function reflects down-regulation and/or dysfunction of triggering receptors involved in natural cytotoxicity. Eur J Immunol. 2004;34(11):3028-38. https://doi.org/10.1002/eji.200425418.

6. Chiossone L, et al. Molecular analysis of the methylprednisolone-mediated inhibition of NK-cell function: evidence for different susceptibility of IL-2- versus IL-15-activated NK cells. Blood. 2007;109(9):3767-75. https:// doi.org/10.1182/blood-2006-07-037846.

7. Le Blanc K, Mougiakakos D. Multipotent mesenchymal stromal cells and the innate immune system. Nat Rev Immunol. 2012;12(5):383-96. https:// doi.org/10.1038/nri3209.

8. Shi Y, et al. Mesenchymal stem cells: a new strategy for immunosuppression and tissue repair. Cell Res. 2010;20(5):510-8. https://doi.org/10.1038/ cr.2010.44.

9. Klimczak A, Kozlowska U. Mesenchymal stromal cells and tissuespecific progenitor cells: their role in tissue homeostasis. Stem Cells Int. 2016;2016:1-11. https://doi.org/10.1155/2016/4285215.

10. Najar M, Raicevic G, Fayyad-Kazan H, Bron D, Toungouz M, Lagneaux L. Mesenchymal stromal cells and immunomodulation: a gathering of regulatory immune cells. Cytotherapy. 2016;18(2):160-71. https://doi.org/ 10.1016/j.jcyt.2015.10.011.

11. Bienvenu J, Monneret G, Fabien N, Revillard JP. The clinical usefulness of the measurement of cytokines. Clin Chem Lab Med. 2000;38(4):267-85. https://doi.org/10.1515/CCLM.2000.040.

12. Lee MW, Ryu S, Kim DS, Sung KW, Koo HH, Yoo KH. Strategies to improve the immunosuppressive properties of human mesenchymal stem cells. Stem Cell Res Ther. 2015;6(1):179. https://doi.org/10.1186/ s13287-015-0178-y.

13. A. Bernards et al., A class I antigen, HLA-G, expressed in human trophoblasts. Science 1989; 3860, 0-3.

14. Aldrich CL. HLA-G genotypes and pregnancy outcome in couples with unexplained recurrent miscarriage. Mol Hum Reprod. 2001;7(12):116772. https://doi.org/10.1093/molehr/7.12.1167.

15. Ishitani A, Geraghty DE. Alternative splicing of HLA-G transcripts yields proteins with primary structures resembling both class I and class II 
antigens. Proc Natl Acad Sci USA. 1992;89(9):3947-51. https://doi.org/ 10.1073/pnas.89.9.3947.

16. Spaggiari GM, Abdelrazik H, Becchetti F, Moretta L. MSCs inhibit monocyte-derived DC maturation and function by selectively interfering with the generation of immature DCs: central role of MSC-derived prostaglandin E2. Blood. 2009;113(26):6576-83. https://doi.org/10. 1182/blood-2009-02-203943.

17. Kuschner, "乳鼠心肌提取 HHS Public Access. Physiol Behav. 2017; 176(3), 139-148. https://doi.org/10.1016/j.physbeh.2017.03.040

18. Amodio G, Gregori S, Distinctive immunological functions of HLA-G. 2011.

19. Hu C, Li L. Preconditioning influences mesenchymal stem cell properties in vitro and in vivo. J Cell Mol Med. 2018;22(3):1428-42. https://doi. org/10.1111/jcmm.13492.

20. Wyles CC, Houdek MT, Wyles SP, Wagner ER, Behfar A, Sierra RJ. Differential Cytotoxicity of Corticosteroids on Human Mesenchymal Stem Cells. Clin Orthop Relat Res. 2015;473(3):1155-64. https://doi.org/10. 1007/s11999-014-3925-y.

21. Shintani N, Hunziker EB. Differential effects of dexamethasone on the chondrogenesis of mesenchymal stromal cells: influence of microenvironment, tissue origin and growth factor. Eur Cells Mater. 2011;22:30220. https://doi.org/10.22203/eCM.v022a23.

22. Xiao Y, Peperzak V, van Rijn L, Borst J, de Bruijn J. Dexamethasone treatment during the expansion phase sustains stemness of mesenchymal stem cells from human bone marrow. Cell Res. 2008;18(S1):S116-S116. https://doi.org/10.1038/cr.2008.206.

23. Nandy SB, Mohanty S, Singh M, Behari M, Airan B, Fibroblast growth factor-2 alone as an efficient inducer for differentiation of human bone marrow mesenchymal stem cells into dopaminergic neurons. pp. 1-10; 2014.

24. Rawat S, Srivastava P, Mohanty S, Prabha P, Gupta S, Kanga U. A comparative study on immunomodulatory potential of tissue specific hMSCs: role of HLA-G mesenchymal stem cells in immunomodulation: a potential candidate for therapeutic intervention? View project evaluation of therapeutic potential of tissue specific M. IOSR J Dent Med Sci e-ISSN. 2018;17(6):32-40. https://doi.org/10.9790/0853-1706143240.

25. Kakkar A, Sharma P, Sankar MM, Kharbanda O, Mohanty S. Effect of hypoxia on stemness and differentiation of dental pulp derived stem cells. IOSR J Dent Med Sci. 2016;15(08):102-11. https://doi.org/10.9790/ 0853-150807102111.

26. Chen W, et al. Immunomodulatory effects of mesenchymal stromal cells-derived exosome. Immunol Res. 2016;64(4):831-40. https://doi. org/10.1007/s12026-016-8798-6.

27. Dominici $M$, et al. Minimal criteria for defining multipotent mesenchymal stromal cells. The international society for cellular therapy position statement. Cytotherapy. 2006;8(4):315-7. https://doi.org/10.1080/ 14653240600855905.

28. Akhter A, Faridi RM, Das V, Pandey A, Naik S, Agrawal S, In vitro upregulation of HLA-G using dexamethasone and hydrocortisone in first-trimester trophoblast cells of women experiencing recurrent miscarriage. 2012; 8:126-135. https://doi.org/10.1111/j.1399-0039. 2012.01884.

29. Akhter A, Das V, Pandey A, Agrawal S, Effect of glucocorticoids on transcriptional status of HLA-G in human trophoblast cells from full term placenta. 2010; 10(4):223-229.

30. Le Blanc K, et al. Mesenchymal stem cells for treatment of steroidresistant, severe, acute graft-versus-host disease: a phase II study. Lancet. 2008;371(9624):1579-86. https://doi.org/10.1016/S0140-6736(08) 60690-X.
31. Shi Y, Su J, Roberts Al, Shou P, Rabson AB, Ren G. How mesenchymal stem cells interact with tissue immune responses. Trends Immunol. 2012;33(3):136-43. https://doi.org/10.1016/j.it.2011.11.004.

32. Chen $X$, et al. The interaction between mesenchymal stem cells and steroids during inflammation. Cell Death Dis. 2014;5:1-12. https://doi. org/10.1038/cddis.2013.537.

33. Lin TH, et al. Decreased osteogenesis in mesenchymal stem cells derived from the aged mouse is associated with enhanced NF-KB activity. J Orthop Res. 2017;35(2):281-8. https://doi.org/10.1002/jor.23270.

34. Chan WK, Lau AS-Y, Li JC-B, Law HK-W, Lau YL, Chan GC-F." MHC expression kinetics and immunogenicity of mesenchymal stromal cells after short-term IFN- $\gamma$ challenge. Exp Hematol. 2008;36(11):1545-55. https:// doi.org/10.1016/j.exphem.2008.06.008.

35. Prasanna SJ, Gopalakrishnan D, Shankar SR, Vasandan AB. Pro-inflammatory cytokines, IFNY and TNFa, influence immune properties of human bone marrow and Wharton jelly mesenchymal stem cells differentially. PLOS ONE. 2010;5(2):e9016. https://doi.org/10.1371/journal.pone.00090 16.

36. Schneider $\mathrm{N}$ et al., Dexamethasone and azathioprine promote cytoskeletal changes and affect mesenchymal stem cell migratory behavior. pp 1-20; 2015. https://doi.org/10.1371/journal.pone.0120538.

37. Wang H, Pang B, Li Y, Zhu D, Pang T, Liu Y. Dexamethasone has variable effects on mesenchymal stromal cells. Cytotherapy. 2012;14(4):423-30. https://doi.org/10.3109/14653249.2011.652735.

38. Song IH, Kim SY. Effects of dexamethasone on proliferation of mesenchymal stem cells in long term culture. Korean J Phys Anthropol. 2007;20(4):311. https://doi.org/10.11637/kjpa.2007.20.4.311.

39. Hong $D$, et al. Osteoblastogenic effects of dexamethasone through upregulation of TAZ expression in rat mesenchymal stem cells. J Steroid Biochem Mol Biol. 2009;116(1-2):86-92. https://doi.org/10.1016/j.jsbmb. 2009.05.007.

40. Lu X, et al. PGE2 Promotes the migration of mesenchymal stem cells through the activation of FAK and ERK1/2 Pathway. Stem Cells Int. 2017;2017:1-11. https://doi.org/10.1155/2017/8178643.

41. Ma S, Xie N, Li W, Yuan B, Shi Y, Wang Y. Immunobiology of mesenchymal stem cells. Cell Death Differ. 2014;21(2):216-25. https://doi.org/10.1038/ cdd.2013.158.

42. Sheng $\mathrm{H}$, et al. A critical role of IFNy in priming MSC-mediated suppression of T cell proliferation through up-regulation of B7-H1. Cell Res. 2008;18(8):846-57. https://doi.org/10.1038/cr.2008.80.

43. Meesuk L, Tantrawatpan C, Kheolamai P, Manochantr S. The immunosuppressive capacity of human mesenchymal stromal cells derived from amnion and bone marrow. Biochem Biophys Reports. 2016;8:34-40. https://doi.org/10.1016/j.bbrep.2016.07.019.

44. Ankrum JA, Dastidar RG, Ong JF, Levy O, Karp JM. Performance-enhanced mesenchymal stem cells via intracellular delivery of steroids. Sci Rep. 2014. https://doi.org/10.1038/srep04645.

45. Moreau P, et al. Glucocorticoid hormones upregulate levels of HLA-G transcripts in trophoblasts. Transplant Proc. 2001;33(3):2277-80. https:// doi.org/10.1016/S0041-1345(01)01990-X.

46. Michelo CM, et al. Added effects of dexamethasone and mesenchymal stem cells on early Natural Killer cell activation. Transpl Immunol. 2016;37:1-9. https://doi.org/10.1016/j.trim.2016.04.008.

\section{Publisher's Note}

Springer Nature remains neutral with regard to jurisdictional claims in published maps and institutional affiliations. 